\title{
Spin Crossover in New Iron(II) Coordination Compounds with Tris(pyrazol-1-yl)Methane
}

\author{
Olga G. Shakirova ${ }^{1,2, *}$ and Ludmila G. Lavrenova ${ }^{2,3}$ \\ 1 Department of Chemistry and Chemical Technologies, Faculty of Machinery and Chemical Technologies, \\ Federal State Budget Institution of Higher Education, Komsomolsk-na-Amure State University, \\ Lenin Ave. 27, 681013 Komsomolsk-on-Amur, Russia \\ 2 Department of Chemistry of Coordination, Cluster and Supramolecular Compounds, \\ Laboratory of Synthesis of Complex Compounds, Federal State Budget Institution for Science, \\ Nikolaev Institute of Inorganic Chemistry, Siberian Branch of the Russian Academy of Sciences, \\ Acad. Lavrentyev Ave. 3, 630090 Novosibirsk, Russia; ludm@niic.nsc.ru \\ 3 Department of Analytical Chemistry, Faculty of Natural Sciences, Novosibirsk State University, \\ Pirogov Str. 2, 630090 Novosibirsk, Russia \\ * Correspondence: Shakirova_Olga@mail.ru; Tel.: +7-962-296-7481
}

Received: 27 August 2020; Accepted: 19 September 2020; Published: 22 September 2020

\begin{abstract}
We review here new advances in the synthesis and investigation of iron(II) coordination compounds with tris(pyrazol-1-yl)methane and its derivatives as ligands. The complexes demonstrate thermally induced spin crossover accompanied by thermochromism. Factors that influence the nature and temperature of the spin crossover are discussed.
\end{abstract}

Keywords: spin crossover; thermochromism; coordination compounds; iron(II); tris(pyrazol-1-yl)methane

\section{Introduction}

Spin crossover (SCO) is the change in spin multiplicity under the influence of external conditions, representing one of the most interesting phenomena in the field of coordination chemistry of $\mathrm{Cr}^{2+}$, $\mathrm{Mn}^{2+/ 3+}, \mathrm{Fe}^{2+/ 3+}$, and $\mathrm{Co}^{2+/ 3+}[1-3]$. The most common and widely used external factor that causes a spin crossover is temperature (referred to as TIESST-thermally induced excited spin state trapping). However, there are examples of other external stimuli capable of switching the spin state of SCO-active complexes, such as pressure [4], an external magnetic field [5], light of a certain wavelength (LIESST-light-induced excited spin state trapping) [6], and light-controlled ligand isomerization (LDLISC-ligand-driven light-induced spin change) [7] and solvation/desolvation [8].

The interest of our investigation predominantly focuses on six-coordinate iron(II) complexes with the following change of electron configurations and ligand field states: ${ }^{1} A_{1}\left(t_{2 g}^{6} e_{g}^{0}=\right.$ low spin, LS $) \leftrightarrow{ }^{5} T_{2}\left(t_{2 g}^{4} e_{g}^{2}=\right.$ high spin, $\left.\boldsymbol{H S}\right)$. The most widely studied systems in which the SCO phenomenon is observed are hexacoordinated iron (II) complexes with the coordination core $\mathrm{FeN}_{6}$ [9-12]. In many of these complexes, the six donor nitrogen atoms surrounding the iron ion belong to different heterocycles, imines, and/or amines. Nevertheless, it was shown that other donor atoms can also be used to obtain compounds with SCO (moreover, not only octahedral, but also other coordination numbers) [13]. Six donor atoms can belong to both six molecules (monodentate ligands), or three (bidentate ligands), two (tridentate/tripodal), and even one (hexadentate ligand). Note that $\mathrm{SCO}$ is not always (and not only) realized in complexes with the $\mathrm{FeN}_{6}$ node. The current level of development of the synthetic direction of coordination chemistry convincingly proves the importance of many factors but does not provide a $100 \%$ guarantee of the successful production of a material with the desired properties. Therefore, the authors of research works pay great attention to the methods and 
conditions of synthesis, isolation, storage, and identification. The chemical, physical, and in particular, magnetic properties of iron (II) complexes are different and unique.

Minor tweaks in spin state energetics between different compounds are measurable via the SCO equilibrium midpoint temperature $\left(\mathrm{T}_{\frac{1}{2}}\right)$. Another SCO temperature $\left(\mathrm{T}_{\mathrm{c}}\right)$ is obtained as the top of the derivative of magnetic susceptibility with respect to temperature $\partial \chi / \partial \mathrm{T}$. The SCO temperature during heating $\left(T_{c} \uparrow\right)$ and cooling $\left(T_{c} \downarrow\right)$ can differ significantly, their difference is called the width of the hysteresis loop: $\Delta \mathrm{T}_{\mathrm{c}}=\mathrm{T}_{\mathrm{c}} \uparrow-\mathrm{T}_{\mathrm{c}} \downarrow$.

The synthesis of new thermosensitive magnetically active compounds-affordable, environmentally friendly, changing the spin state at different temperatures-is an important task for a chemist. Moreover, thermally induced SCO is provided by a change in the magnetic moment and color (oftentimes, but not always) [14]. These properties determine whether these compounds can be used as materials for information recording and storage systems, displays [15,16], electroluminescent devices [17], and temperature-sensitive contrast agents in magnetic resonance imaging [18]. These compounds could be used as thermochromic indicators and labels in engineering processes and in the security industry $[3,19]$.

This review is a logical extension of our paper [20] and is devoted to the latest studies of spin crossover in Fe(II) complexes with tris(pyrazol-1-yl)methane $\left(\mathbf{H C}(\mathbf{p z})_{3}\right)$ and its derivatives (Figure 1). We will give a comparative characteristic with bis(B-scorpionate) iron(II) complexes, but we will not touch on the third-fifth generation of scorpionates, which are well described in [21,22]. The steric aspects of ligand design for the control of the metal ion spin state are clear enough. Bulky substituents in the vicinity of the ligand donor atoms that disfavor contraction of the metal-ligand bonds will stabilize the HS state of a complex. A steric bulk at the periphery of the ligand sphere can promote the LS state if it inhibits the expansion of the metal coordination sphere, or the HS state if it leads to distortion of the ligand-metal dative interaction. These effects can be reliably understood or predicted in single compounds using molecular modeling [23].
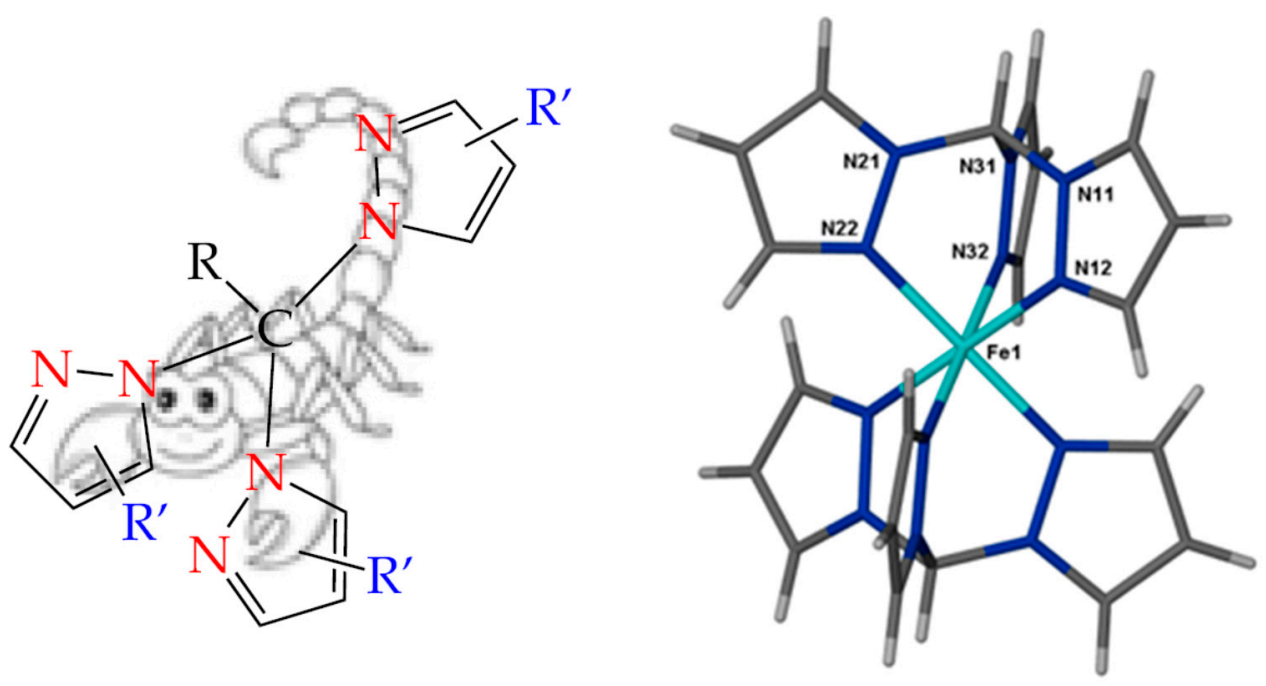

Figure 1. Schematic structure of C-scorpionate tris(pyrazol-1-yl)methanes $R C\left(R^{\prime}-p z\right)_{3}$ (pz = pyrazolyl; $\mathrm{R}=\mathrm{H}$ or substituent at the methine carbon; $\mathrm{R}^{\prime}=\mathrm{H}$ or any substituent at the $\mathrm{pz}$ ring) and comparison with a scorpion; and the structure of the complex cation $\left[\mathrm{Fe}\left(\mathrm{HC}(\mathrm{pz})_{3}\right\}_{2}\right]^{2+}$.

\section{Discussion}

Tris(pyrazol-1-yl)methane $\left(\mathrm{HC}(\mathrm{pz})_{3}\right)$, tris(pyrazol-1-yl)borate $\left(\mathrm{HB}(\mathrm{pz})_{3}\right)^{-}$, and their derivatives are isotypic ligands that show promising prospects for the SCO. The most important feature of these compounds is the presence in the three pyrazole cycles of $\mathrm{N}$ atoms capable of coordination to a metal leading to the formation of an octahedral complex with the coordination core $\mathrm{FeN}_{6}$ in the case of the coordination of two ligands. For iron(II) compounds, this means that there is 
the possibility of SCO. It was shown that these ligands are coordinated to the metal mainly in a tridentate mode (symmetry group $\mathrm{C}_{3}$ ) [24-26]. In the case of $\left(\mathrm{HB}(\mathrm{pz})_{3}\right)^{-}$, a neutral complex is formed, $\left[\mathrm{Fe}\left(\mathrm{HB}(\mathrm{pz})_{3}\right)_{2}\right]$ [27]. Any modification of the ligand leads to a change in the inner sphere of the complex and its properties $[28,29]$. In the case of $\left(\mathrm{HC}(\mathrm{pz})_{3}\right)$, cationic complexes are formed, $\left[\mathrm{Fe}\left(\mathrm{HC}(\mathrm{pz})_{3}\right)_{2}\right]^{2+}$. Hence, the researcher can modify the ligand and replace the anion to study the effect on the properties of not only the internal sphere of the complex, but also the external one. In addition, for both types of complexes, the influence of the crystallization solvent must be taken into account [30-33].

The synthesis of several iron(II) compounds with unsubstituted $\left(\mathrm{HB}(\mathrm{pz})_{3}\right)^{-}$and $\mathrm{HC}(\mathrm{pz})_{3}$, such as $\left[\mathrm{Fe}\left(\mathrm{HB}(\mathrm{pz})_{3}\right)_{2}\right]$ and $\left[\mathrm{Fe}\left(\mathrm{HC}(\mathrm{pz})_{3}\right)_{2}\right] \mathrm{A}_{2}\left(\mathrm{~A}=\mathrm{Br}^{-}, \mathrm{ClO}_{4}{ }^{-}, \mathrm{BF}_{4}{ }^{-}\right)$, was described lightly in the last century; specifically, $\left[\mathrm{Fe}\left(\mathrm{HB}(\mathrm{pz})_{3}\right)_{2}\right]$, which is low-spin up to $280 \mathrm{~K}$ and then a gradual change to $4.91 \mu \mathrm{B}$ at 461 $\mathrm{K}$, typical of the high-spin state; it also undergoes a spin state crossover to the high-spin state upon heating to $420 \mathrm{~K}$ and at high pressure [27]. Similarly, variable-temperature magnetic susceptibility measurement in the solid state of the complexes $\left[\mathrm{Fe}\left(\mathrm{HC}(\mathrm{pz})_{3}\right)_{2}\right]\left(\mathrm{ClO}_{4}\right)_{2}$ and $\left[\mathrm{Fe}\left(\mathrm{HC}(\mathrm{pz})_{3}\right)_{2}\right]\left(\mathrm{BF}_{4}\right)_{2}$ suggest the existence of single-quintet spin crossover with the single isomer largely favored at room temperature, a spin crossover to the high-spin state undergoes upon heating [34-36], while the complex $\left[\mathrm{Fe}\left(\mathrm{HC}(\mathrm{pz})_{3}\right)_{2}\right] \mathrm{Br}_{2}$ was recognized as diamagnetic [25], which was questioned by us.

In the paper [37], the crystal structures of $\alpha$ and $\beta$ polymorphs of $\left[\mathrm{Fe}\left(\mathrm{HC}(\mathrm{pz})_{3}\right)_{2}\right]\left(\mathrm{NO}_{3}\right)_{2}$ were reported. The density of the $\beta$ form is considerably greater than that of the $\alpha$. Some considerations are changes in the angular parameters $\mathrm{N}-\mathrm{Fe}-\mathrm{N}$, and associated variations in the angles exocyclic to the various five- and six-membered rings. Unfortunately, the authors were not able to obtain enough of the $\alpha$ isomer to measure its magnetic properties for comparison. The $\beta$ polymorph showed a slight temperature dependence of $\mu_{\text {eff }}$ over the range $4-350 \mathrm{~K}$, with $\mu_{\text {eff }}$ being essentially constant at $1.05 \mu \mathrm{B}$ between 50 and $270 \mathrm{~K}$ and then increasing gradually to $1.26 \mu \mathrm{B}$ at $350 \mathrm{~K}$. We continued their work and showed with the help of DSC (Figure 2) that the main changes are observed at higher temperatures: $\mathrm{T}_{\text {onset }} \uparrow=427.9 \mathrm{~K}, \mathrm{~T}_{\text {onset }} \downarrow=415.3 \mathrm{~K}, \Delta \mathrm{H}_{\mathrm{tr}}=13.9 \pm 0.3 \mathrm{~kJ} / \mathrm{mol}, \Delta \mathrm{S}_{\mathrm{tr}}=\Delta \mathrm{H} / \mathrm{T}_{1 / 2}=32.3 \pm 0.8 \mathrm{~J} \cdot \mathrm{mol}^{-1} \cdot \mathrm{K}^{-1}$.

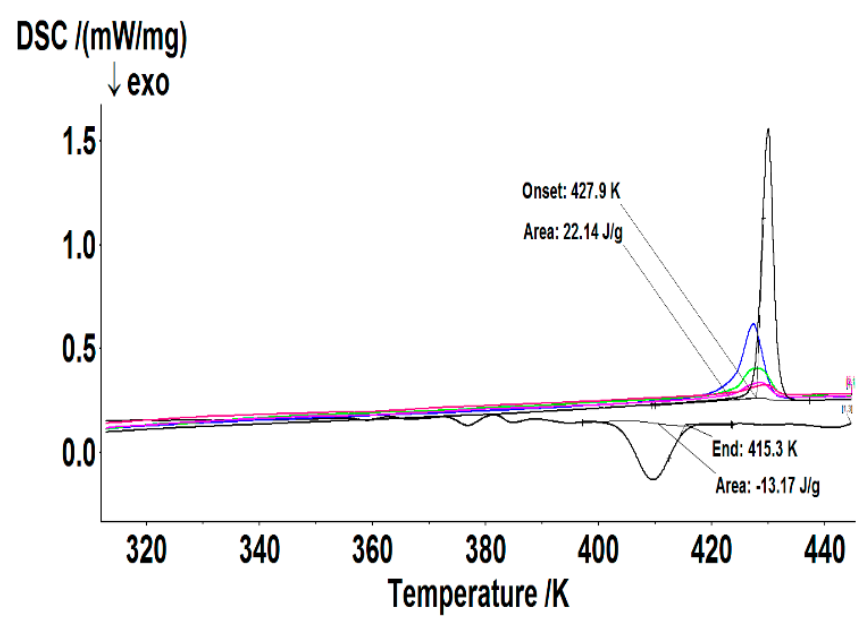

Figure 2. Termal analysis $(\mathrm{DSC})$ of $\left[\mathrm{Fe}\left(\mathrm{HC}(\mathrm{pz})_{3}\right)_{2}\right]\left(\mathrm{NO}_{3}\right)_{2}$.

The spin crossover observed upon cooling and at high pressure in the iron(II) complexes formed with various methyl derivatives of mentioned ligands span a variety of different behaviors. $\left[\mathrm{Fe}\left(\mathrm{HB}\left(3,5-\left(\mathrm{CH}_{3}\right)_{2} \mathrm{pz}\right)_{3}\right)_{2}\right]$, which is high-spin at $295 \mathrm{~K}$, undergoes a spin state crossover to the low-spin state both upon cooling below $195 \mathrm{~K}$ and at high pressure. Tris(3,5-dimethylpyrazole-1-yl)methanide $\left(\mathrm{C}\left(3,5-\left(\mathrm{CH}_{3}\right)_{2} \mathrm{pz}\right)_{3}\right)^{-}$obtained by deprotonation of tris(3,5-dimethylpyrazole-1-yl)methane was also used as a ligand for iron (II). However, for the $\left[\mathrm{Fe}\left(\mathrm{C}\left(3,5-\left(\mathrm{CH}_{3}\right)_{2} \mathrm{pz}\right)_{3}\right)_{2}\right]$ complex, there is a sharp SCO with a small hysteresis with $\mathrm{T}_{1 / 2}=267 \mathrm{~K}$ [38]. Exposed carbanion centers that are located outwards are available for further reactions. 
In contrast, $\left[\mathrm{Fe}\left(\mathrm{HB}\left(3,4,5-\left(\mathrm{CH}_{3}\right)_{3} \mathrm{pz}\right)_{3}\right)_{2}\right]$ remains high-spin between 1.9 and $295 \mathrm{~K}$ but is gradually converted to the low-spin state with increasing pressure. In a parallel fashion, $\left[\mathrm{Fe}\left(\mathrm{HC}\left(3,5-\left(\mathrm{CH}_{3}\right)_{2} \mathrm{pz}\right)_{3}\right)_{2}\right] \mathrm{I}_{2}$ is high-spin at $295 \mathrm{~K}$. The sharp and complete transitions with a hysteresis in the $\mu_{\text {eff }}(\mathrm{T})$ curves are observed in the single-crystal phase of $\left[\mathrm{Fe}\left(\mathrm{HC}\left(3,5-\left(\mathrm{CH}_{3}\right)_{2} \mathrm{pz}\right)_{3}\right)_{2}\right] \mathrm{I}_{2}[35,39]$ and in the polycrystalline phase of $\left[\mathrm{Fe}\left(\mathrm{HC}\left(3,5-\left(\mathrm{CH}_{3}\right)_{2} \mathrm{pz}\right)_{3}\right)_{2}\right]\left(\mathrm{NO}_{3}\right)_{2}[40]$. In $\left[\mathrm{Fe}\left(\mathrm{HC}\left(3,5-\left(\mathrm{CH}_{3}\right)_{2} \mathrm{pz}\right)_{3}\right)_{2}\right]\left(\mathrm{BF}_{4}\right)_{2}$, which is high-spin at $295 \mathrm{~K}$, a phase transition exhibits upon cooling below $206 \mathrm{~K}$ in which only one-half of the iron(II) is converted to the low-spin state; the remaining one-half of the iron(II) remains high-spin upon cooling to $4.2 \mathrm{~K}$ [41]. The sharp but incomplete transition is observed also in complex $\left[\mathrm{Fe}\left(\mathrm{HC}\left(3,5-\left(\mathrm{CH}_{3}\right)_{2} \mathrm{pz}\right)_{3}\right)_{2}\right]\left(\mathrm{ClO}_{4}\right)_{2}$ [42]. In $\left[\mathrm{Fe}\left(\mathrm{HC}\left(3,5-\left(\mathrm{CH}_{3}\right)_{2} \mathrm{pz}\right)_{3}\right)_{2}\right] \mathrm{I}_{2}$ and $\left[\mathrm{Fe}\left(\mathrm{HC}\left(3,5-\left(\mathrm{CH}_{3}\right)_{2} \mathrm{pz}\right)_{3}\right)_{2}\right]\left(\mathrm{ClO}_{4}\right)_{2}$, spin crossovers are observed only in single crystals, while the polycrystalline phases exhibit no spin crossover. Note that two polymorphous modifications were observed for single crystals in the latter case. The spin crossover is observed in one modification isostructural to $\left[\mathrm{Fe}\left(\mathrm{HC}\left(3,5-\left(\mathrm{CH}_{3}\right)_{2} \mathrm{pz}\right)_{3}\right)_{2}\right]\left(\mathrm{BF}_{4}\right)_{2}$, while no spin crossover is observed in the second modification [42].

By now, we synthesized the complexes $\left[\mathrm{Fe}\left(\mathrm{HC}(\mathrm{pz})_{3}\right)_{2}\right] \mathrm{A}_{2} \cdot \mathrm{nH}_{2} \mathrm{O}$, here $\mathrm{A}=\mathrm{Cl}^{-}, \mathrm{Br}^{-}, \mathrm{I}^{-}, \mathrm{NO}_{3}{ }^{-}$, $\mathrm{CF}_{3} \mathrm{SO}_{3}{ }^{-}, \mathrm{C}_{10} \mathrm{H}_{7} \mathrm{SO}_{3}{ }^{-}, \mathrm{C}_{12} \mathrm{H}_{25} \mathrm{SO}_{4}^{-}, 7,8-\mathrm{C}_{2} \mathrm{~B}_{9} \mathrm{H}_{12}{ }^{-}, \mathrm{C}_{2} \mathrm{~B}_{9} \mathrm{H}_{8} \mathrm{Br}_{4}{ }^{-}, \mathrm{C}_{2} \mathrm{~B}_{9} \mathrm{H}_{8} \mathrm{I}_{4}^{-}, \mathrm{C}_{2} \mathrm{~N}_{3}{ }^{-}, \mathrm{C}_{8} \mathrm{H}_{5} \mathrm{O}_{4}{ }^{-}, \mathrm{ReO}_{4}{ }^{-}$, $\left[\mathrm{B}\left(\mathrm{C}_{6} \mathrm{H}_{5}\right)_{4}\right]^{-},\left[\mathrm{Ni}(\mathrm{dmit})_{2}\right]^{-}, \mathrm{TCNQ}^{-} ;\left[\mathrm{Fe}\left(\mathrm{HC}(\mathrm{pz})_{3}\right)_{2}\right] \mathrm{A} \cdot \mathrm{nH}_{2} \mathrm{O}$, here $\mathrm{A}=\mathrm{SO}_{4}{ }^{2-}, \mathrm{SiF}_{6}{ }^{2-},\left[\mathrm{Mo}_{6} \mathrm{Br}_{14}\right]^{2-}$, $\left[\mathrm{Mo}_{6} \mathrm{Cl}_{14}\right]^{2-},\left[\mathrm{W}_{6} \mathrm{I}_{14}\right]^{2-},\left[\mathrm{W}_{6} \mathrm{Br}_{14}\right]^{2-},\left[\mathrm{W}_{6} \mathrm{Cl}_{14}\right]^{2-}, \mathrm{B}_{10} \mathrm{H}_{10}{ }^{2-}, \mathrm{B}_{10} \mathrm{Cl}_{10}{ }^{2-}, \mathrm{B}_{12} \mathrm{H}_{12}{ }^{2-},[\text { Eu(dipic) })_{2}$ (Hdipic) $]^{2-}$, $\left[\mathrm{Fe}(\mathrm{NO})(\mathrm{CN})_{5}\right]^{2-} ; \mathrm{n}=0-7 ;$ and $\left[\mathrm{Fe}\left(\mathrm{HC}(\mathrm{pz})_{3}\right)_{2}\right]_{2}\left[\mathrm{Re}_{6} \mathrm{~S}_{8}(\mathrm{CN})_{6}\right] \cdot 2 \mathrm{H}_{2} \mathrm{O}$ [43-49]. Complexes were obtained by an exchange reaction between water-alcohol solutions of $\mathrm{FeSO}_{4}(\mathrm{C} \approx 0.05 \mathrm{~mol} / \mathrm{L})$ and $\mathrm{HC}(\mathrm{pz})_{3}$ with an aqueous solution of salt of the respective anion with a different ratio of iron:ligand:anion, which is usually 1:2-6:3-6. Most of the synthesized iron(II) complexes with $\mathrm{HC}(\mathrm{pz})_{3}$ are stable on storing in the air at room temperature for a long time and non-hygroscopic.

These compounds were studied by static magnetic susceptibility, diffuse reflectance, IR spectroscopy, and powder and single-crystal X-ray diffraction (XRD). We determined the molecular and crystal structure parameters for most of the isolated compounds. According to the XRD data, the complexes are mononuclear and have an octahedral structure of the coordination polyhedron, with $\mathrm{FeN}_{6}$ being the coordination core. The $\mathrm{Fe}-\mathrm{N}$ bond lengths in the complex cations are in the range 1.96-1.98 $\AA$, which corresponds to the LS form of an iron(II) complex. In the crystals, the complex cations exhibit small distortion of the octahedral polyhedron. The values of the deviation of the coordination polyhedron from the ideal octahedron are calculated and shown in the Table 1, the parameters $\mathrm{F}$ and $\Sigma$ are introduced by the authors [50,51]. For example, Table 2 demonstrates changes in geometric characteristics of the iron(II) environment in complex $\left[\mathrm{Fe}\left(\mathrm{HC}(\mathrm{pz})_{3}\right)_{2}\right]_{\mathrm{SiF}_{6}}$ at heating. From these data, you can see that the spin crossover is accompanied by a significant change in all crystallographic parameters: $\Delta \mathrm{d}(\mathrm{Fe}-\mathrm{N})=0.1391 \AA(7.0 \%) ; \Delta a=0.0536 \AA(0.4 \%) ; \Delta c=0.3639 \AA(2.7 \%)$; $\Delta \mathrm{V}=69.8 \AA^{3}(3.6 \%) ; \Delta \rho=-0.06938 \mathrm{~g} / \mathrm{cm}^{3}(3.4 \%)$.

In cases where good single crystals were not obtained for X-ray diffraction analysis, the geometry of high- and low-spin complexes with various anions of the outer sphere was studied by EXAFS spectroscopy, which is suitable for studying the geometry of the local environment of atoms and ions both in crystalline solids and in systems without long-range ordering. Experimental EXAFS spectra [46] show the first maximum corresponding to the electron wave scattering on nitrogen atoms of the first coordination sphere iron ion, and the second maximum, which corresponds to scattering on second-order nitrogen atoms coordination sphere. Upon the transition of the complexes from the LS to the HS state, the Fourier function maxima are shifted toward larger scattering, and their intensities become considerably weaker. The Fourier functions for the samples before and after heating are almost identical, which points to the reversibility of SCO. The interatomic distances obtained by simulation of EXAFS spectra are summarized in Table 3. 
Table 1. Basic geometric characteristics of the iron(II) environment in complexes at $\mathrm{T}=150 \mathrm{~K}$.

\begin{tabular}{|c|c|c|c|}
\hline Complex & $\mathrm{d}(\mathrm{Fe}-\mathrm{N})_{\text {average }}$ & $\Sigma=\sum_{i=1}^{12}\left|\alpha_{i}^{c i s}-90\right|,{ }^{\circ}$ & $F=\frac{1}{24} \sum_{i=1}^{24}\left|\alpha_{i}^{t r i}-60\right|^{\circ}$ \\
\hline$\left[\mathrm{Fe}\left(\mathrm{HC}(\mathrm{pz})_{3}\right)_{2}\right]\left(\mathrm{CF}_{3} \mathrm{SO}_{3}\right)_{2}$ & 1.9645 & 30.948 & 1.497 \\
\hline$\left[\mathrm{Fe}\left(\mathrm{HC}(\mathrm{pz})_{3}\right)_{2}\right] \mathrm{SiF}_{6}$ & 1.9732 & 27.06 & 1.269 \\
\hline$\left[\mathrm{Fe}\left(\mathrm{HC}(\mathrm{pz})_{3}\right)_{2}\right]\left(\mathrm{C}_{8} \mathrm{H}_{5} \mathrm{O}_{4}\right)_{2} \cdot \mathrm{C}_{8} \mathrm{H}_{6} \mathrm{O}_{4}$ & 1.9682 & 31.36 & 1.513 \\
\hline$\left[\mathrm{Fe}\left(\mathrm{HC}(\mathrm{pz})_{3}\right)_{2}\right]\left[\mathrm{Fe}\left(\mathrm{HC}(\mathrm{pz})_{3}\right)(\mathrm{NCS})_{3}\right](\mathrm{NCS}) \cdot 2 \mathrm{H}_{2} \mathrm{O}$ & 1.9697 & 29.745 & 1.43 \\
\hline$\left[\mathrm{Fe}\left(\mathrm{HC}(\mathrm{pz})_{3}\right)_{2}\right]_{5}(\mathrm{C}[4] \mathrm{AS})_{2} \cdot 62 \mathrm{H}_{2} \mathrm{O}$ & 1.9632 & 31.472 & 1.576 \\
\hline$\left[\mathrm{Fe}\left(\mathrm{HC}(\mathrm{pz})_{3}\right)_{2}\right] \mathrm{I}_{2}$ & 1.9743 & 27.24 & 1.402 \\
\hline$\left[\mathrm{Fe}\left(\mathrm{HC}(\mathrm{pz})_{3}\right)_{2}\right] \mathrm{SO}_{4} \cdot 7 \mathrm{H}_{2} \mathrm{O}$ & 1.9578 & 28.228 & 1.375 \\
\hline$\left[\mathrm{Fe}\left(\mathrm{HC}(\mathrm{pz})_{3}\right)_{2}\right]\left(\mathrm{ReO}_{4}\right)_{2}$ & 1.9643 & 30.76 & 1.544 \\
\hline$\left[\mathrm{Fe}\left(\mathrm{HC}(\mathrm{pz})_{3}\right)_{2}\right] \mathrm{Cl}_{2} \cdot 2 \mathrm{H}_{2} \mathrm{O}$ & 1.9687 & 35.264 & 1.697 \\
\hline$\left[\mathrm{Fe}\left(\mathrm{HC}(\mathrm{pz})_{3}\right)_{2}\right]\left[\mathrm{Eu}(\text { dipic })_{2}(\right.$ Hdipic $\left.)\right] \cdot 4 \mathrm{H}_{2} \mathrm{O}$ & 1.9682 & 31.666 & 1.66 \\
\hline $\left.\mathrm{Fe}\left(\mathrm{HC}(\mathrm{pz})_{3}\right)_{2}\right]\left(\mathrm{C}_{12} \mathrm{H}_{25} \mathrm{SO}_{4}\right)_{2}$ & 1.9617 & 29.488 & 1.475 \\
\hline$\left[\mathrm{Fe}\left(\mathrm{HC}(\mathrm{pz})_{3}\right)_{2}\right]\left(\mathrm{NO}_{3}\right)_{2} \cdot \mathrm{H}_{2} \mathrm{O}$ & 1.9616 & 28.016 & 1.372 \\
\hline$\left[\mathrm{Fe}\left(\mathrm{HC}(\mathrm{pz})_{3}\right)_{2}\right]\left(\mathrm{C}_{10} \mathrm{H}_{7} \mathrm{SO}_{3}\right)_{2} \cdot 2 \mathrm{H}_{2} \mathrm{O}$ & 1.9661 & 28.19 & 1.359 \\
\hline$\left[\mathrm{Fe}\left(\mathrm{HC}(\mathrm{pz})_{3}\right)_{2}\right] \mathrm{Br}_{2}$ & 1.9663 & 25.166 & 1.28 \\
\hline
\end{tabular}

Table 2. Basic geometric characteristics of the iron(II) environment in complex $\left[\mathrm{Fe}\left(\mathrm{HC}(\mathrm{pz})_{3}\right)_{2}\right] \mathrm{SiF}_{6}$.

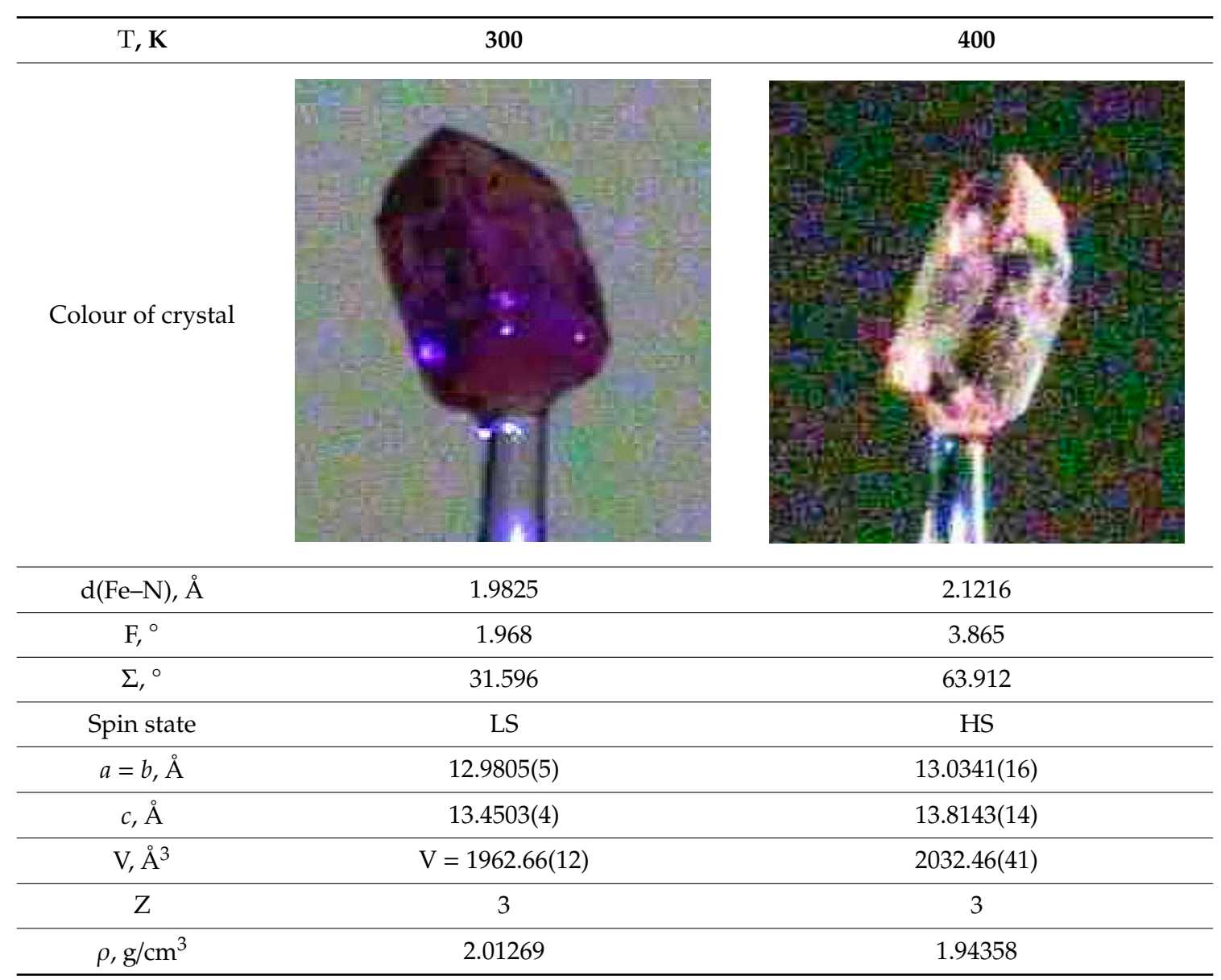


Table 3. Modeling of experimental Fe K-edge EXAFS spectra. $\mathrm{Fe}-\mathrm{N}_{1}$ and $\mathrm{Fe}-\mathrm{N}_{2}$ are average distances to the nitrogen atoms in the environment of the iron atom.

\begin{tabular}{|c|c|c|c|c|c|c|}
\hline \multirow{2}{*}{ Complex } & \multicolumn{2}{|c|}{$\begin{array}{c}300 \mathrm{~K}(\mathrm{LS}) \\
\text { before Heating }\end{array}$} & \multicolumn{2}{|c|}{$475 \mathrm{~K}$ (HS) } & \multicolumn{2}{|c|}{$\begin{array}{c}300 \mathrm{~K} \text { (LS) } \\
\text { after Cooling }\end{array}$} \\
\hline & $\begin{array}{c}R, \stackrel{\AA}{\mathrm{A}} \pm 0.01 \\
\mathrm{Fe}-\mathrm{N}_{1}\end{array}$ & $\begin{array}{c}R, \stackrel{\AA}{\mathrm{A}} \pm 0.01 \\
\mathrm{Fe}-\mathrm{N}_{2}\end{array}$ & $\begin{array}{c}R, \AA \pm 0.01 \\
\quad \mathrm{Fe}-\mathrm{N}_{1}\end{array}$ & $\begin{array}{c}R, \AA \pm 0.01 \\
\quad \mathrm{Fe}-\mathrm{N}_{2}\end{array}$ & $\begin{array}{c}R, \AA \pm 0.01 \\
\quad \mathrm{Fe}-\mathrm{N}_{1}\end{array}$ & $\begin{array}{c}R, \AA \pm 0.01 \\
\quad \mathrm{Fe}-\mathrm{N}_{2}\end{array}$ \\
\hline$\left[\mathrm{Fe}\left(\mathrm{HC}(\mathrm{pz})_{3}\right)_{2}\right] \mathrm{B}_{10} \mathrm{Cl}_{10}$ & 1.96 & 2.89 & 2.09 & 2.98 & 1.96 & 2.89 \\
\hline$\left[\mathrm{Fe}\left(\mathrm{HC}(\mathrm{pz})_{3}\right)_{2}\right] \mathrm{B}_{10} \mathrm{H}_{10}$ & 1.96 & 2.89 & 2.13 & 3.01 & 1.96 & 2.89 \\
\hline$\left[\mathrm{Fe}\left(\mathrm{HC}(\mathrm{pz})_{3}\right)_{2}\right] \mathrm{B}_{12} \mathrm{H}_{12} \cdot 2 \mathrm{H}_{2} \mathrm{O}$ & 1.96 & 2.91 & 2.15 & 3.03 & 1.96 & 2.91 \\
\hline
\end{tabular}

The IR spectra analysis of these compounds in the range of metal-ligand stretching vibrations (200-400 $\mathrm{cm}^{-1}$ ) and the comparison with the literature data [52] show that at room temperature some complexes contain iron(II) not only in LS $\left(\mathrm{Fe}_{\mathrm{LS}}\right)$ but also HS ( $\left.\mathrm{Fe}_{\mathrm{HS}}\right)$ states. Composite bands within the range $348-382 \mathrm{~cm}^{-1}$ can be assigned to stretching $v\left(\mathrm{Fe}_{\mathrm{HC}}-\mathrm{N}\right)$ vibrations, and the bands at $265-298 \mathrm{~cm}^{-1}$ can be assigned to $v\left(\mathrm{Fe}_{\mathrm{BC}}-\mathrm{N}\right)$.

IR spectroscopy data easily reveal that the composition of complexes contain crystal water molecules (the range $3400-3600 \mathrm{~cm}^{-1}$ ). An analysis of the position of absorption bands in the range $1400-1600 \mathrm{~cm}^{-1}$ is most informative for the conclusion about the ways of coordination of heterocyclic ligands. In the spectrum of $\mathrm{HC}(\mathrm{pz})_{3}$ in the range $1428-1566 \mathrm{~cm}^{-1}$, there are bands corresponding to stretching-bending vibrations of pyrazole rings, which are sensitive to coordination. In the spectra of complexes, these bands are observed in the range 1440-1515 $\mathrm{cm}^{-1}$. Hence, in comparison with the spectrum of $\mathrm{HC}(\mathrm{pz})_{3}$, they are noticeably shifted, which indicates the coordination of nitrogen atoms of the pyrazole ring to the iron(II) ion. Comparing the IR spectra of powder samples with the spectra of crystal complexes of the same composition, we can conclude that in all mentioned compounds $\mathrm{HC}(\mathrm{pz})_{3}$ is a tridentate cyclic ligand coordinated to iron(II) ions by $\mathrm{N}(2)$ nitrogen atoms of pyrazole rings.

In [53], the influence of temperature on the character of IR spectra was studied. When the samples are heated (Figure 3), there is a sharp increase in the band intensity at $850 \mathrm{~cm}^{-1}$ and a decrease in the band intensity at $865 \mathrm{~cm}^{-1}$. The intensity of the band increases at $1000 \mathrm{~cm}^{-1}$, the intensity of the bands at 1450 and $1410 \mathrm{~cm}^{-1}$ decreases, and the band $1515 \mathrm{~cm}^{-1}$ increases moderately. Almost all bands undergo a $5-10 \mathrm{~cm}^{-1}$ shift to the low frequency region when the samples are heated. All these trends are reproduced in B3LYP calculations for an isolated $\left[\mathrm{Fe}\left(\mathrm{HC}(\mathrm{pz})_{3}\right)_{2}\right]^{2+}$ cation. (Some computational details for the B3LYP calculations are in the Supplementary Materials.)

The electronic spectra (diffuse reflectance spectra, DRS) of the transition in the complexes at room temperature exhibit a single band in the range $480-570 \mathrm{~nm}$ that can be attributed to the $\mathrm{d}-\mathrm{d}$ transition ${ }^{1} \mathrm{~A}_{1} \rightarrow{ }^{1} \mathrm{~T}_{1}$ in a strong octahedral ligand field. The positions of these bands are consistent with our previous data for LS iron(II) complexes with 1,2,4-triazoles (Htrz), which have a $\mathrm{FeN}_{6}$ core and possess SCO [54].

Using the DRS data $\left(\nu, \mathrm{cm}^{-1}\right)$ obtained at room temperature, we estimated the strength of the ligand field (parameter $\Delta_{\mathrm{LS}}, \mathrm{cm}^{-1}$ ) of tris(pyrazol-1-yl)methane in complexes. The following approximations valid for octahedral nitrogen-containing complexes of iron(II) were applied: $v\left({ }^{1} A_{1} \rightarrow{ }^{1} T_{1}\right)=\Delta_{\mathrm{LS}}-\mathrm{C}+86 \cdot \mathrm{B}^{2} / \Delta_{\mathrm{LS}} ;$ with regard to that, $\mathrm{B}_{\text {free ion }}=917 \mathrm{~cm}^{-1}$ [55]; $\mathrm{B} \approx(0.7 \div 0.8) \mathrm{B}_{\text {free ion }} \approx 690 \mathrm{~cm}^{-1}$, and $\mathrm{C}=4.41 \mathrm{~B} \approx 3040 \mathrm{~cm}^{-1}$ [56]. The obtained $v$ values are in the range $17,540-20,830 \mathrm{~cm}^{-1}$; the calculated $\Delta_{\text {LS }}$ values changes within $18,500-22,000 \mathrm{~cm}^{-1}$. It is seen that the anion nature and size appreciably affect the ligand field strength. The condition $19,000 \mathrm{~cm}^{-1} \leq \Delta_{\mathrm{LS}} \leq 23,000 \mathrm{~cm}^{-1}$ [55] that causes the appearance of SCO at heating, is fulfilled (it is satisfied within a $3 \%$ relative error).

In addition, the complexes with cluster anions that have a second broad absorption band are observed in the near IR range. Bands with the maxima at 835-860 nm can be assigned to the $\mathrm{d}$-d-transition ${ }^{5} \mathrm{~T}_{2} \rightarrow{ }^{5} \mathrm{Ein}$ a weakly distorted octahedral ligand field. The position of these bands is typical of the spectra of HS octahedral complexes of iron(II) with 
nitrogen-containing ligands [20]. From these data, it is possible to easily calculate the values $v\left({ }^{5} \mathrm{~T}_{2} \rightarrow{ }^{5} \mathrm{E}\right)=\Delta_{\mathrm{HS}}=11,630-11,980 \mathrm{~cm}^{-1}$, where $\Delta_{\mathrm{HS}}$ is the splitting parameter in the crystalline field of HS Fe(II) complexes. The splitting parameters indicate that in these complexes SCO is theoretically possible at cooling because $11,000 \mathrm{~cm}^{-1} \leq \Delta_{\mathrm{HS}} \leq 12,500 \mathrm{~cm}^{-1}$ [57].

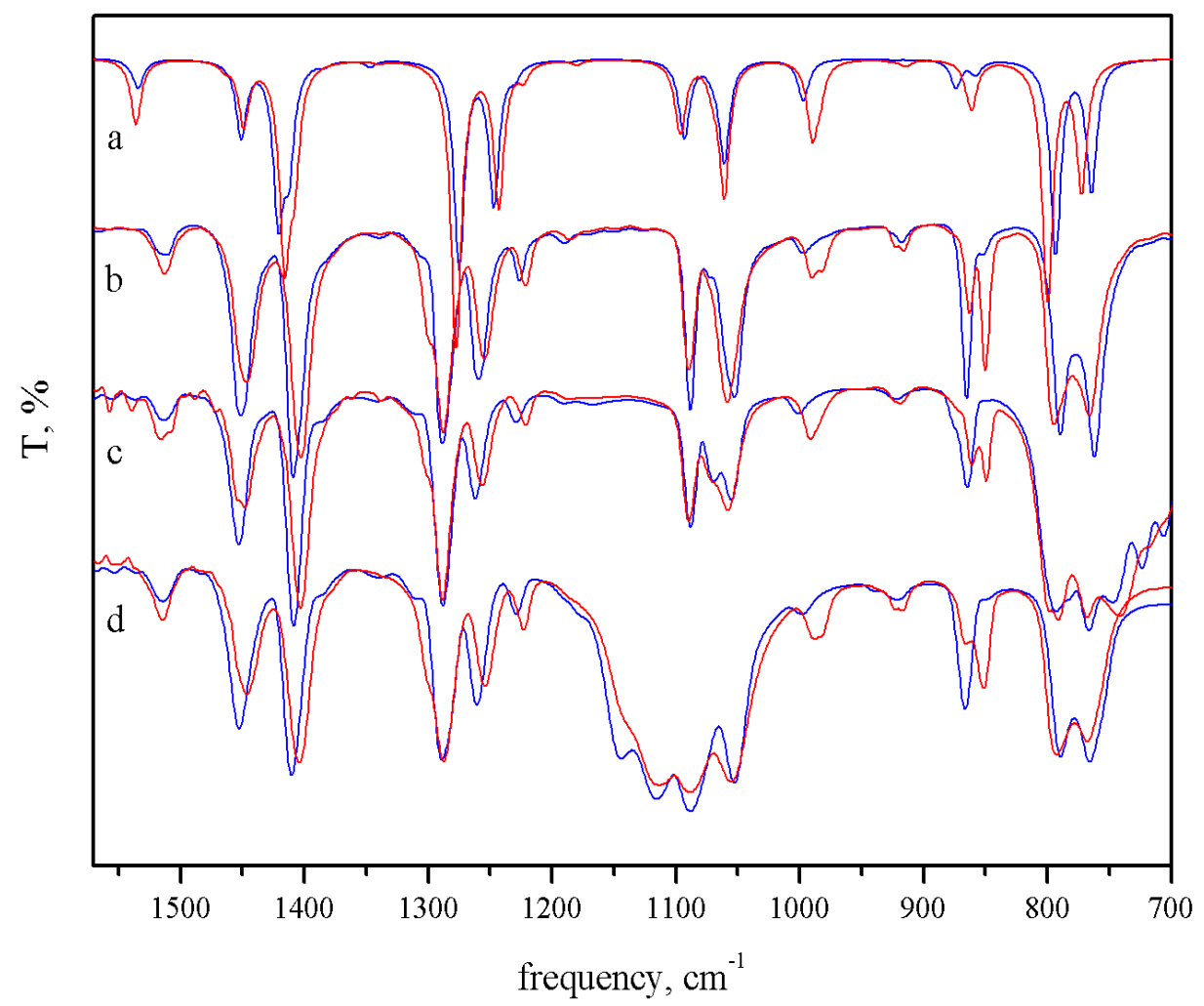

Figure 3. Influence of the metal spin state on the IR spectra of $\mathrm{Fe}(\mathrm{II})$ complexes with tris(pyrazol-1-yl)methane: (a)—B3LYP $\left[\mathrm{Fe}\left(\mathrm{HC}(\mathrm{pz})_{3}\right)_{2}\right]^{2+} ;(\mathbf{b})-\left[\mathrm{Fe}\left(\mathrm{HC}(\mathrm{pz})_{3}\right)_{2}\right] \mathrm{I}_{2} ;(\mathbf{c})-\left[\mathrm{Fe}\left(\mathrm{HC}(\mathrm{pz})_{3}\right)_{2}\right] \mathrm{SiF}_{6}$; $(\mathbf{d})-\left[\mathrm{Fe}\left(\mathrm{HC}(\mathrm{pz})_{3}\right)_{2}\right]\left(\mathrm{ClO}_{4}\right)_{2}$; the blue line indicates LS state; the red line shows HS state.

Let us present our calculations showing that tris(pyrazol-1-yl)methanes are ligands of a stronger field compared to 1,2,4-triazoles (Table 4).

Table 4. Splitting parameters for HS- and LS-complexes of iron(II) with 1,2,4-triazoles and tris(pyrazol-1-yl)methanes.

\begin{tabular}{|c|c|c|c|c|c|c|}
\hline Complex & Spin State & $\Delta E, \mathrm{~cm}^{-1}$ & $B, \mathrm{~cm}^{-1}$ & $C, \mathrm{~cm}^{-1}$ & $10 D q_{H S}, \mathrm{~cm}^{-1}$ & $10 D q_{L S}, \mathrm{~cm}^{-1}$ \\
\hline \multirow{2}{*}{$\mathrm{Fe}(\mathrm{Htrz})_{3} \mathrm{~A}_{2}$} & HS & $11,100-11,770$ & \multirow{2}{*}{600} & \multirow{2}{*}{2650} & \multirow{2}{*}{$11,100-11,770$} & \multirow{2}{*}{$\begin{array}{c}19,240-20,360 \\
(21,120-21,230[57])\end{array}$} \\
\hline & LS & $18,200-19,230$ & & & & \\
\hline \multirow{2}{*}{$\mathrm{Fe}\left(\mathrm{NH}_{2} \mathrm{trz}\right)_{3} \mathrm{~A}_{2}$} & HS & $10,870-12,990$ & \multirow{2}{*}{630} & \multirow{2}{*}{2780} & \multirow{2}{*}{$10,870-12,990$} & \multirow{2}{*}{$\begin{array}{c}18,480-19,740 \\
(20,450[57])\end{array}$} \\
\hline & LS & $17,550-18,690$ & & & & \\
\hline \multirow{2}{*}{$\mathrm{Fe}\left(4-\mathrm{C}_{2} \mathrm{H}_{5}-\operatorname{trz}\right)_{3} \mathrm{~A}_{2}$} & HS & $11,630-11,770$ & \multirow{2}{*}{620} & \multirow{2}{*}{2730} & \multirow{2}{*}{$11,630-11,770$} & \multirow{2}{*}{18,830} \\
\hline & LS & 17,860 & & & & \\
\hline \multirow{2}{*}{$\mathrm{Fe}\left(4-\mathrm{C}_{3} \mathrm{H}_{7}-\operatorname{trz}\right)_{3} \mathrm{~A}_{2}$} & HS & $11,400-11,800$ & \multirow{2}{*}{610} & \multirow{2}{*}{2690} & \multirow{2}{*}{$11,400-11,800$} & \multirow{2}{*}{18,460} \\
\hline & LS & 17,500 & & & & \\
\hline$\left[\mathrm{Fe}\left(\mathrm{HC}(\mathrm{pz})_{3}\right)_{2}\right] \mathrm{A}_{2}$ & HS & $18,690-20,830$ & 690 & 3040 & & $19,650-22,010$ \\
\hline$\left[\mathrm{Fe}\left(\mathrm{HC}\left(3,5-\left(\mathrm{CH}_{3}\right)_{2} \mathrm{pz}\right)_{3}\right)_{2}\right] \mathrm{A}$ & LS & $12,900-14,600$ & 720 & 3180 & $12,900-14,600$ & \\
\hline
\end{tabular}

The magnetochemical investigation of the series of complexes demonstrated that they all exhibit reversible $\mathrm{SCO}^{1} \mathrm{~A}_{1} \leftrightarrow{ }^{5} \mathrm{~T}_{2}$, most often with small hysteresis on the $\mu_{\text {eff }}(\mathrm{T})$ curves (Figure 4 ). 


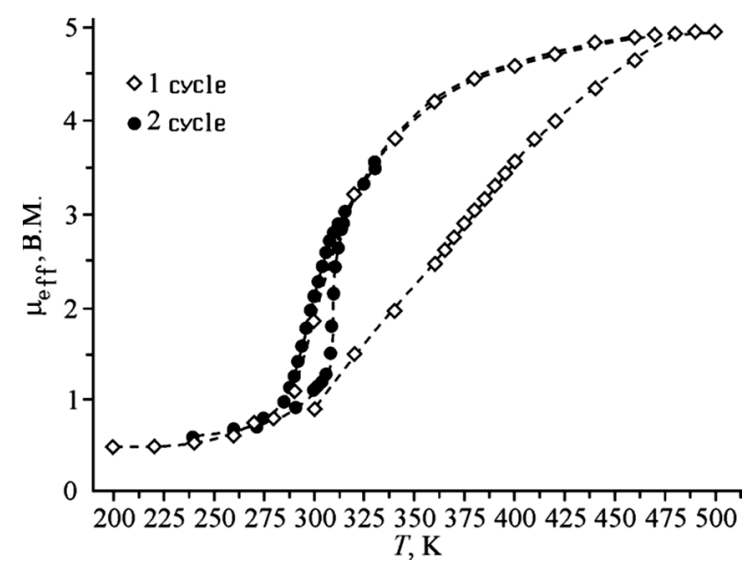

(a) $\left[\mathrm{Fe}\left(\mathrm{HC}(\mathrm{pz})_{3}\right)_{2}\right]\left(\mathrm{SO}_{3} \mathrm{CF}_{3}\right)_{2}$ (pink $\leftrightarrow$ white)

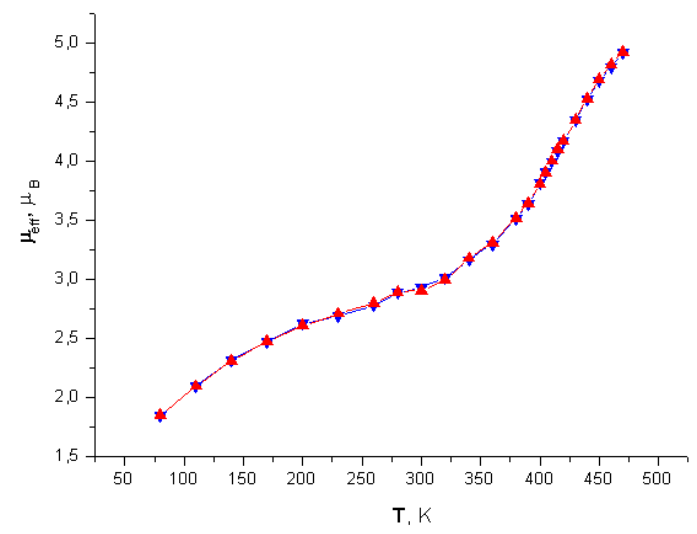

(c) $\left[\mathrm{Fe}\left(\mathrm{HC}(\mathrm{pz})_{3}\right)_{2}\right]\left[\mathrm{Eu}(\text { dipic })_{2}\right.$ (Hdipic) $]$ (pink $\leftrightarrow$ white)

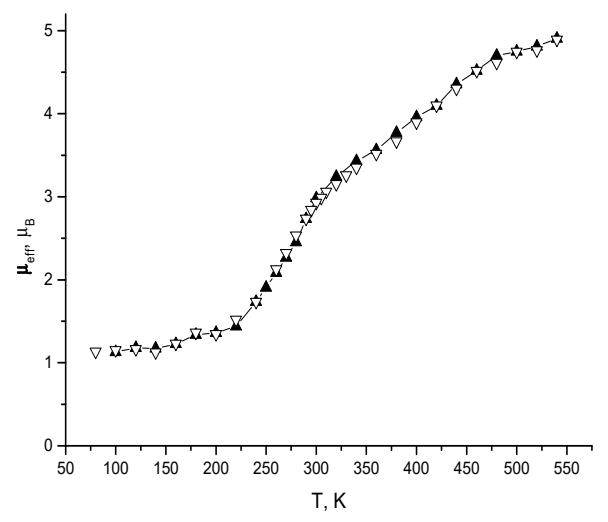

(e) $\left[\mathrm{Fe}\left\{\mathrm{HC}(\mathrm{pz})_{3}\right\}_{2}\right]\left[\left\{\mathrm{W}_{6}\left(\mu_{3}-\mathrm{Cl}\right)_{8}\right\} \mathrm{Cl}_{6}\right]$ (pink $\leftrightarrow$ beige $\leftrightarrow$ yellow)

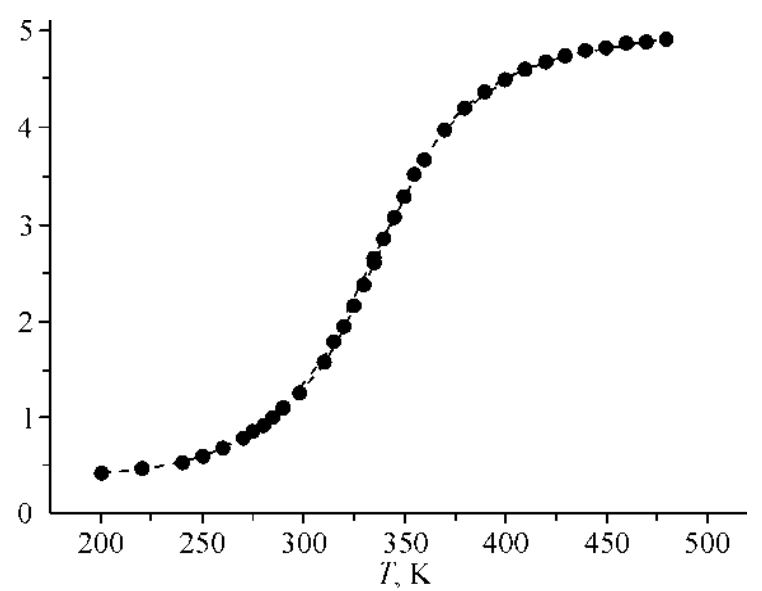

(b) $\left[\mathrm{Fe}\left(\mathrm{HC}(\mathrm{pz})_{3}\right)_{2}\right] \mathrm{SiF}_{6}$ (purple $\leftrightarrow$ white)

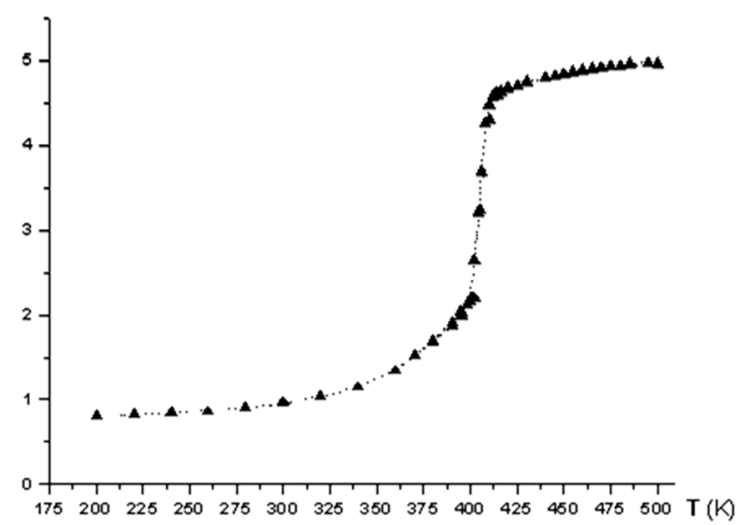

(d) $\left[\mathrm{Fe}\left(\mathrm{HC}(\mathrm{pz})_{3}\right)_{2}\right] \mathrm{B}_{12} \mathrm{H}_{12}$ (purple $\leftrightarrow$ white)

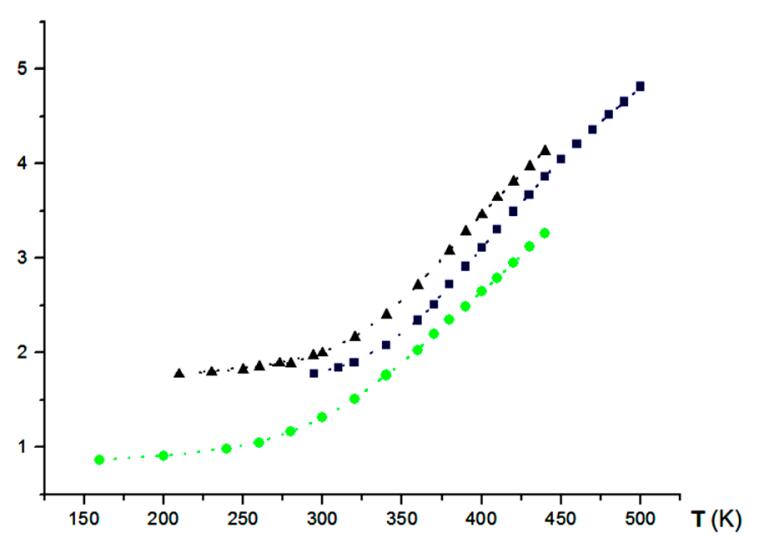

(f) $\boldsymbol{\Delta}-\left[\mathrm{Fe}\left\{\mathrm{HC}(\mathrm{pz})_{3}\right\}_{2}\right]\left(1,5,6,10-\mathrm{Br}_{4}-7,8-\mathrm{C}_{2} \mathrm{~B}{ }_{9} \mathrm{H}_{8}\right)_{2}$; - - $\left[\mathrm{Fe}\left\{\mathrm{HC}(\mathrm{pz})_{3}\right\}_{2}\right]\left(1,5,6,10-\mathrm{I}_{4}-7,8-\mathrm{C}_{2} \mathrm{~B}_{9} \mathrm{H}_{8}\right)_{2}$; - - $\left[\mathrm{Fe}\left\{\mathrm{HC}(\mathrm{pz})_{3}\right\}_{2}\right]\left(7,8-\mathrm{C}_{2} \mathrm{~B}_{9} \mathrm{H}_{8}\right)_{2} ;($ pink $\leftrightarrow$ white)

Figure 4. An example of $\mu_{\mathrm{eff}}(\mathrm{T})$ dependences: (a) — spin crossover (SCO) with hysteresis; (b)—SCO without hysteresis; (c)-incomplete SCO with exchange interactions between metal ions of an antiferromagnetic nature; (d)—complete and sharp SCO; (e)—two stage SCO; (f) —incomplete and continuous SCO. 
In all cases, the transition is accompanied by a thermochromic effect. The complex $\left.\left[\mathrm{Fe}\left(\mathrm{HC}(\mathrm{pz})_{3}\right)_{2}\right)\right]\left(\mathrm{CF}_{3} \mathrm{SO}_{3}\right)_{2}$ possessed a different behavior for three measurements, which were revolved. The first measurement demonstrated fairly complete SCO in the $\mu_{\text {eff }}(\mathrm{T})$ curve with a large hysteresis loop. The temperatures of the direct $\left(T_{c} \uparrow\right)$ and reverse $\left(T_{c} \downarrow\right)$ transitions are 375 and $300 \mathrm{~K}$, respectively. In the second and third cycles of measurements, an abrupt transition was observed with $\mathrm{T}_{\mathfrak{c}} \uparrow$ and $\mathrm{T}_{\mathfrak{c}} \downarrow$ values of 310 and $302 \mathrm{~K}$, respectively. It can be seen that the width of the hysteresis loop is greatly reduced. It is possible to assume that this effect is caused by reaching the equilibrium state in the crystals. This effect was previously found for complexes of iron(II) with 1,2,4-triazoles as ligands [58].

For a correct comparison of the magnetochemical data, complexes were analyzed after dehydration. Below, you can see a series of $\mathrm{T}_{\mathrm{c}} \uparrow(\mathrm{K})$ dependences on the outer-sphere anion:

$$
\begin{gathered}
{\left[\mathrm{W}_{6} \mathrm{Br}_{14}\right]^{2-}\left(240^{*}\right)<\left[\mathrm{W}_{6} \mathrm{I}_{14}\right]^{2-}\left(248^{*}\right)<\left[\mathrm{Mo}_{6} \mathrm{Br}_{14}\right]^{2-}(270)<\left[\mathrm{Mo}_{6} \mathrm{Cl}_{14}\right]^{2-}(271)<\left[\mathrm{W}_{6} \mathrm{Cl}_{14}\right]^{2-}\left(287^{*}\right)<} \\
\mathrm{SO}_{3} \mathrm{CF}_{3}{ }^{-}\left(310^{* *}\right)<\mathrm{SiF}_{6}^{2-}(335)<\left[\mathrm{Re}_{6} \mathrm{~S}_{8}(\mathrm{CN})_{6}\right]^{4-}(383)<\mathrm{I}^{-}(400) \approx \mathrm{SO}_{4}^{2-}(400) \approx \\
{\left[\mathrm{B}\left(\mathrm{C}_{6} \mathrm{H}_{5}\right)_{4}\right]^{-}(400)<\mathrm{ReO}_{4}^{-}(403) \approx \mathrm{PF}_{6}^{-}(403)<\mathrm{Cl}^{-}(410)<\left[\mathrm{Eu}(\text { dipic })_{2}\left(\mathrm{Hdipic}^{-}\right]^{2-}(415)<\right.} \\
\mathrm{C}_{12} \mathrm{H}_{25} \mathrm{SO}_{4}^{-}(420) \approx \mathrm{NO}_{3}^{-}(420)<\mathrm{C}_{10} \mathrm{H}_{7} \mathrm{SO}_{3}^{-}(440)<\mathrm{Br}^{-}(445) \approx \mathrm{TCNQ}^{-}(445)
\end{gathered}
$$

* for a two-stage transition, the value of the first stage is specified; ${ }^{* *}$ for the second/third cycles of measurements.

This series shows no relationship between the anion size and the increase in $\mathrm{T}_{\mathrm{c}}$. In addition, it does not confirm the pattern found earlier for $\mathrm{Fe}(\mathrm{II})$ complexes with 1,2,4-triazoles of the composition $\mathrm{FeL}_{3} \mathrm{~A}_{2}$, where $\mathrm{A}=\mathrm{Cl}^{-}, \mathrm{Br}^{-}, \mathrm{I}^{-}$, in which in the series of anions of one nature, $\mathrm{T}_{\mathrm{c}}$ decreases with an increase in the size of the outer-sphere anion [59].

According to the data for boron-containing complexes, it is possible to derive a series of $\mathrm{T}_{\mathrm{c}} \uparrow(\mathrm{K})$ dependences on the outer-sphere cluster anion:

$$
\begin{gathered}
7,8-\mathrm{C}_{2} \mathrm{~B}_{9} \mathrm{H}_{12}{ }^{-}(370)<1,5,6,10-\mathrm{Br}_{4}-7,8-\mathrm{C}_{2} \mathrm{~B}_{9} \mathrm{H}_{8}^{-}(380)<1,5,6,10-\mathrm{I}_{4}-7,8-\mathrm{C}_{2} \mathrm{~B}_{9} \mathrm{H}_{8}^{-}(400) \\
\mathrm{B}_{10} \mathrm{H}_{10}{ }^{2-}(375)<\mathrm{B}_{12} \mathrm{H}_{12}{ }^{2-}(405) .
\end{gathered}
$$

The given series shows that with an increase in sizes of both closo-borate and carborane (due to the introduction of the substituent) $\mathrm{T}_{\mathrm{c}}$ increases. The opposite trend was observed for SCO coordination polymers, namely, when the anion volume increases, the temperature decreases [60].

It must be noted that the data on the DRS wavelength maxima $\left(\lambda_{\max }, \mathrm{nm}\right)$ for anions (even triple row for anhydrous powdered samples 1,5,6,10- $\mathrm{I}_{4}-7,8-\mathrm{C}_{2} \mathrm{~B}_{9} \mathrm{H}_{8}{ }^{-}(505)<\mathrm{C}_{12} \mathrm{H}_{25} \mathrm{SO}_{4}{ }^{-}(519)<\mathrm{B}_{10} \mathrm{H}_{10}{ }^{2-}$ (520)) allow us to make sure that there is no direct connection between $\mathrm{T}_{\mathrm{c}}$ and $\lambda_{\max }$.

Our work [61] was targeted at preparing and characterizing iron(II) complexes with $\mathrm{HC}\left(3,5-\left(\mathrm{CH}_{3}\right)_{2} \mathrm{pz}\right)_{3}$ that contain two-charge cluster anions, decahydro-closo-decaborate $\left(\mathrm{B}_{10} \mathrm{H}_{10}\right)^{2-}$ and dodecahydro-closo-dodecaborate $\left(\mathrm{B}_{12} \mathrm{H}_{12}\right)^{2-}$. $\mu_{\text {eff }}(\mathrm{T})$ studies show low-temperature incomplete spin crossover (only half of the iron(II) ions have experienced high-to-low spin transition) in [ $\left.\mathrm{Fe}\left(\mathrm{HC}\left(3,5-\left(\mathrm{CH}_{3}\right)_{2} \mathrm{pz}\right)_{3}\right)_{2}\right] \mathrm{B}_{10} \mathrm{H}_{10} \cdot \mathrm{H}_{2} \mathrm{O}$ complex and antiferromagnetic exchange coupling among iron(II) unpaired electrons at temperatures below $90 \mathrm{~K}$ in $\left[\mathrm{Fe}\left(\mathrm{HC}\left(3,5-\left(\mathrm{CH}_{3}\right)_{2} \mathrm{pz}\right)_{3}\right)_{2}\right] \mathrm{B}_{12} \mathrm{H}_{12} \cdot \mathrm{H}_{2} \mathrm{O}$ complex (Figure 5), in contrast to $\left[\mathrm{Fe}\left(\mathrm{HC}(\mathrm{pz})_{3}\right)_{2}\right] \mathrm{B}_{12} \mathrm{H}_{12}$ [46], which has complete and sharp SCO (Figure 4d). Hence, the introduction of alkyl substituents led not only to a decrease in the temperature of the spin transition. In some observed cases, the transition did not occur due to steric difficulties.

A comparison of the properties of the $\left[\mathrm{Fe}\left(\mathrm{HC}(\mathrm{pz})_{3}\right)_{2}\right][\mathrm{Eu} \text { (dipic })_{2}$ (Hdipic)] complex [62] with data for compounds of this class shows that the introduction of a complex anion of "gigantic" size into the crystal lattice did not lead to a significant change in the $\mathrm{T}_{\mathrm{c}}$ and thermal stability of the compound, and there were no noticeable changes in the nature of the $\mu_{\text {eff }}(\mathrm{T})$ dependence curve in the SCO region (Figure 4c). A slight difference in the magnetic behavior of the complex is observed in the low temperature region, where exchange interactions between metal ions of an antiferromagnetic nature are manifested. 


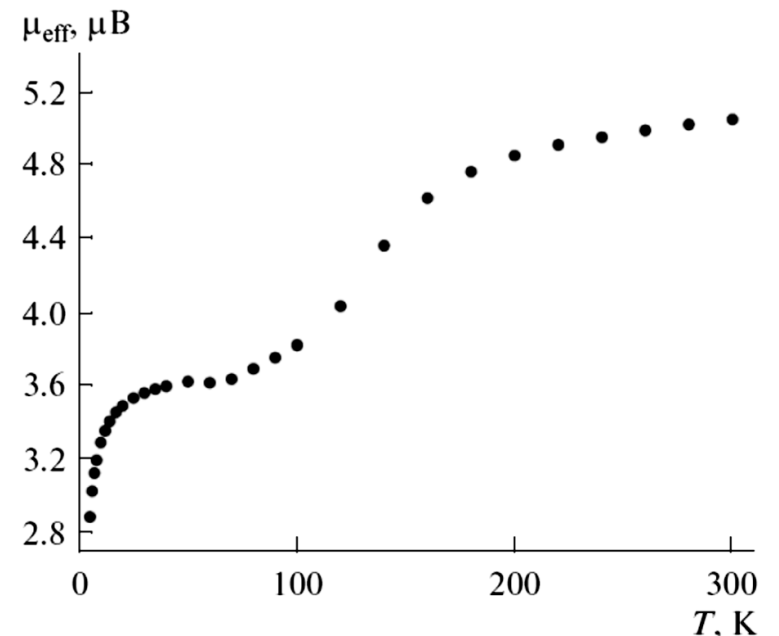

(a) $\left[\mathrm{Fe}\left(\mathrm{HC}\left(3,5-\left(\mathrm{CH}_{3}\right) \mathrm{pz}\right)_{3}\right)_{2}\right] \mathrm{B}_{10} \mathrm{H}_{10} \cdot \mathrm{H}_{2} \mathrm{O}$

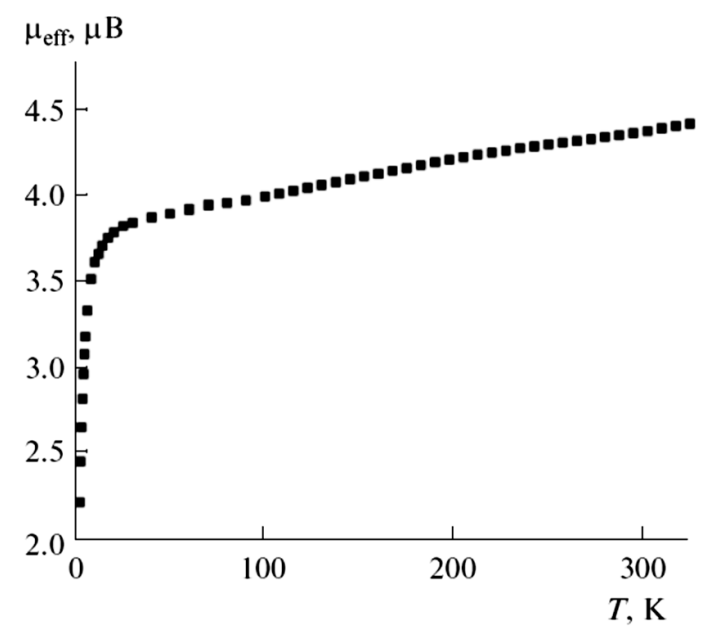

(b) $\left[\mathrm{Fe}\left(\mathrm{HC}\left(3,5-\left(\mathrm{CH}_{3}\right) \mathrm{pz}_{3}\right)_{2}\right] \mathrm{B}_{12} \mathrm{H}_{12} \cdot \mathrm{H}_{2} \mathrm{O}\right.$

Figure 5. $\mu_{\mathrm{eff}}(\mathrm{T})$ plot: (a)-incomplete $\mathrm{SCO}$ with exchange interactions between metal ions of an antiferromagnetic nature; (b) - only exchange interactions between metal ions of an antiferromagnetic nature.

It is of a considerable interest to use the octahedral cation complexes of Fe(II), showing reversible SCO between HS and LS states of the metal ion, as a magnetic subsystem in combination with an anion-conducting subsystem. The conducting sublattice of such hybrid materials were represented by the radical anion subsystem based on $\left[\mathrm{Ni}(\mathrm{dmit})_{2}\right]^{\bullet \delta-}$ complexes (dmit $=4,5$-dithiolato-1,3-dithiole-2-thione; $0<\delta<1$ ) and $7,7,8,8$,-tetracyanoquinodimethane $\left((\mathrm{TCNQ})^{\bullet-}, 0<\delta<1\right)$ in a fractional oxidation or reduction state, respectively (Figure 6). Note, the radical anion salt $\left[\mathrm{Fe}\left(\mathrm{HC}(\mathrm{pz})_{3}\right)_{2}\right](\mathrm{TCNQ})_{3}$ demonstrates unusual for 7,7,8,8,-tetracyanoquinodimethane (TCNQ)-based salts quasi-two-dimensional conductivity, which is interpreted in terms of cross relaxation between the TCNQ and Fe(II) spin subsystems [63]. In the $\left[\mathrm{Fe}\left(\mathrm{HC}(\mathrm{pz})_{3}\right)_{2}\right]\left[\mathrm{Ni}(\mathrm{dmit})_{2}\right]_{2} \cdot 2\left(\mathrm{CH}_{3}\right)_{2} \mathrm{CO}$ complex, radical anions can both dimerize and then break down again into monomers; they can become structurally nonequivalent; they can be shielded by solvent molecules, and they can create stacking layers for electron transport, similarly to [64]. In turn, cations can be in LS and/or HS form, affecting the electrical conductivity of the sample. Hence, the electrical conductivity of the crystals at $300 \mathrm{~K}$ is $2 \cdot 10^{-6} \Omega^{-1} \cdot \mathrm{cm}^{-1}$ for $\left[\mathrm{Fe}\left(\mathrm{HC}(\mathrm{pz})_{3}\right)_{2}\right]\left[\mathrm{Ni}(\mathrm{dmit})_{2}\right]_{2} \cdot 2\left(\mathrm{CH}_{3}\right)_{2} \mathrm{CO}$ and $1.5 \cdot 10^{-2} \Omega^{-1} \cdot \mathrm{cm}^{-1}$ for $\left[\mathrm{Fe}\left(\mathrm{HC}(\mathrm{pz})_{3}\right)_{2}\right](\mathrm{TCNQ})_{3}$, which is millions of times higher than typical values for the SCO-active complexes (for example, $2 \cdot 10^{-14} \Omega^{-1} \cdot \mathrm{cm}^{-1}$ for Fe(Htrz) $)_{2}(\operatorname{trz}) \mathrm{BF}_{4}$ ).

The mononuclear iron(II) complex $\left[\mathrm{Fe}\left(\mathrm{HC}(\mathrm{pz})_{3}\right)_{2}\right](\mathrm{tcp})_{2}$ containing the mono-negative tetracyanopyrrolide (tcp) as a counter-anion was characterized by $\mathrm{X}$-ray diffraction and investigated in the solid state by magnetic susceptibility measurements and differential scanning calorimetry [65]. Structural studies at $123 \mathrm{~K}$ reveal $\mathrm{Fe}-\mathrm{N}$ distances typical for a low-spin iron(II) range between 1.964(4) and 1.979(4) $\AA$. The complex undergoes a gradual, incomplete spin crossover in the examined temperature range $1.9-400 \mathrm{~K}$. The maximal experimental effective moment $\mu_{\text {eff }}$ equals $3.29 \mu \mathrm{B}$ at $400 \mathrm{~K}$, which is close to $T_{1 / 2}$. The authors note, the obtained results are closely related to the tetrafluoroborate salt, where the rapid increase of the effective moment starts at $320 \mathrm{~K}$; the latter rises to $3.24 \mu \mathrm{B}$ at $400 \mathrm{~K}$ and reaches full saturation of HS states at $470 \mathrm{~K}$ based on Mössbauer spectroscopy studies [36]. The compound shows a distinct thermochromism, associated with the spin transition. The color of the sample changes from pink at $77 \mathrm{~K}$ to dark red-violet at $425 \mathrm{~K}$.

For some compounds, substantial residual paramagnetism is observed in the $\mu_{\text {eff }}(\mathrm{T})$ dependence curves at $200 \mathrm{~K}$ (see Figure $4 \mathrm{f}$ ). We estimated the contribution of temperature-independent paramagnetism $\left(\right.$ TIP) by formulas: $\mu_{\text {eff }}(\mathrm{TIP})=\left(8 \chi_{\mathrm{TIP}} \mathrm{T}\right)^{1 / 2}, \chi_{\mathrm{TIP}}=4 / \Delta_{\mathrm{LS}}[66]$. At $\mathrm{T}=200 \mathrm{~K}$ $\mu_{\text {eff }}\left(\right.$ TIP) must not exceed $0.6 \mu \mathrm{B}$. For the calculation we assume that $\mu_{\text {eff }}(\mathrm{HS}) \approx 5.1 \mu \mathrm{B}$ for the class of compounds studied [67]. Then the fractions of the HS form of complexes 
$\left[\mathrm{Fe}\left(\mathrm{HC}(\mathrm{pz})_{3}\right)_{2}\right]\left(1,5,6,10-\mathrm{Br}_{4}-7,8-\mathrm{C}_{2} \mathrm{~B}_{9} \mathrm{H}_{8}\right)_{2}$ and $\left[\mathrm{Fe}\left(\mathrm{HC}(\mathrm{pz})_{3}\right)_{2}\right]\left(1,5,6,10-\mathrm{I}_{4}-7,8-\mathrm{C}_{2} \mathrm{~B}_{9} \mathrm{H}_{8}\right)_{2}$ were calculated by the formula $\alpha(\mathrm{HS})=100 \cdot\left(\mu_{\text {eff }}{ }^{2}-\mu_{\text {eff }}(\text { TIP })^{2}\right) / \mu_{\text {eff }}(\mathrm{HS})^{2}$, are $\sim 10 \%$ at $200 \mathrm{~K}$; hence, each tenth of the iron(II) atoms does not pass into the LS state. A possible reason for the high value of $\alpha(\mathrm{HS})$ can be the existence of structurally non-equivalent forms of the complexes, one of which does not participate in the $\mathrm{SCO}$ process. For the complex $\left[\mathrm{Fe}\left(\mathrm{HC}(\mathrm{pz})_{3}\right)_{2}\right]\left(7,8-\mathrm{C}_{2} \mathrm{~B}_{9} \mathrm{H}_{12}\right)_{2}$ (with the unsubstituted anion), the fraction of the residual HS form calculated similarly is below $0.5 \%$.

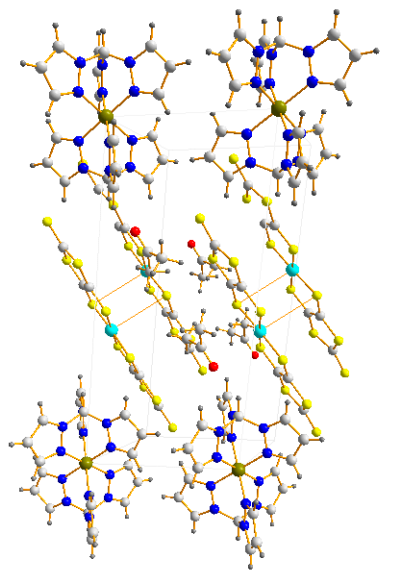

(a) $\left[\mathrm{Fe}\left(\mathrm{HC}(\mathrm{pz})_{3}\right)_{2}\right]\left[\mathrm{Ni}(\mathrm{dmit})_{2}\right]_{2} \cdot 2\left(\mathrm{CH}_{3}\right)_{2} \mathrm{CO}$

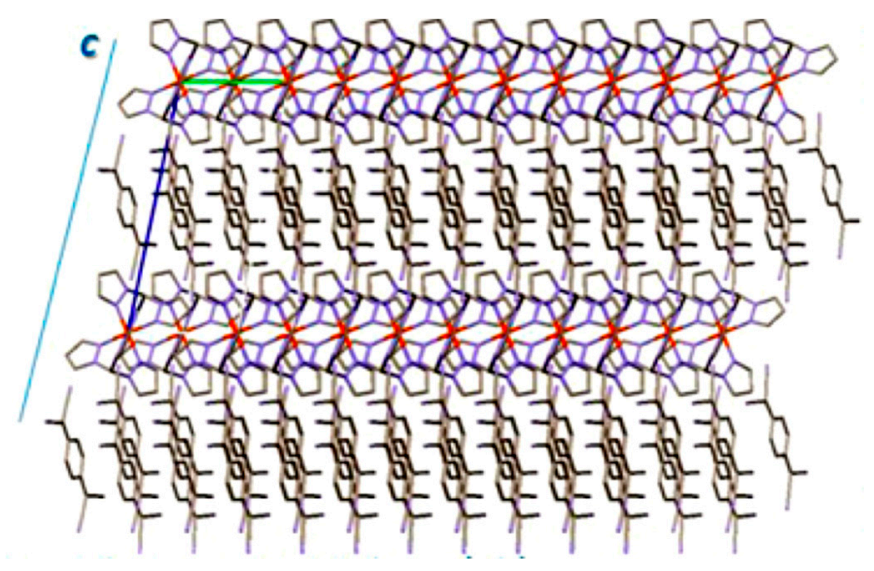

(b) $\left[\mathrm{Fe}\left(\mathrm{HC}(\mathrm{pz})_{3}\right)_{2}\right](\mathrm{TCNQ})_{3}$

Figure 6. Fragment of the crystal packing with showing alternate cationic and anionic layers: (a)-Coordination interactions $\mathrm{Ni} \cdots \mathrm{S}$ in the anionic dimers and interlayer $\mathrm{C}-\mathrm{H} \cdots \mathrm{S}$ contacts (2.81-2.96 A) between cations and anions; (b) - Stacking interactions in the anionic columns and interlayer $\mathrm{C}-\mathrm{H} \cdots \mathrm{N}$ contacts $(2.41-2.70 \AA$ ) between cations and anions (conducting TCNQ plane $(\mathbf{a}, \mathbf{b})$ )).

Complexes of iron(II) thiocyanate with this class of ligands differ significantly their structures. The typical complex $\left[\mathrm{Fe}\left(\mathrm{HC}\left(3,5-\left(\mathrm{CH}_{3}\right)_{2} \mathrm{pz}\right)_{3}\right)_{2}\right](\mathrm{NCS})_{2}$ [68] does not change its HS state with the temperature decreasing to $40 \mathrm{~K}$; then the decreasing $\mu_{\text {eff }}$ indicates exchange interactions of the antiferromagnetic character. For complexes $\left[\mathrm{Fe}\left(\mathrm{HC}(\mathrm{pz})_{3}\right)_{2}\right]\left[\mathrm{Fe}\left(\mathrm{HC}(\mathrm{pz})_{3}\right)(\mathrm{NCS})_{3}\right] \mathrm{NCS} \cdot 2 \mathrm{H}_{2} \mathrm{O}[67]$ and $\left[\mathrm{Fe}\left(\mathrm{HC}\left(3,5-\left(\mathrm{CH}_{3}\right)_{2} \mathrm{pz}\right)_{3}\right)_{2}\right]\left[\mathrm{Fe}\left(\mathrm{HC}\left(3,5-\left(\mathrm{CH}_{3}\right)_{2} \mathrm{pz}\right)_{3}\right)(\mathrm{NCS})_{3}\right]_{2}[68]$ (in both cation and complex anion), tris(pyrazol-1-yl)methanes coordinate via the tridentate cyclic mode. In addition, the anions have the octahedral coordination core $\mathrm{FeN}_{6}$ due to three $\mathrm{N}$ atoms of three isocyanate groups (Figure 7). The SCO is exhibited only by the complex with cation $\mathrm{Fe}\left[\left(\mathrm{HC}(\mathrm{pz})_{3}\right)_{2}\right]^{2+}\left(\mathrm{T}_{\mathrm{c}}=380 \mathrm{~K}\right)$ (Figure 8), whereas other particles remain in the HS state over the entire temperature range.
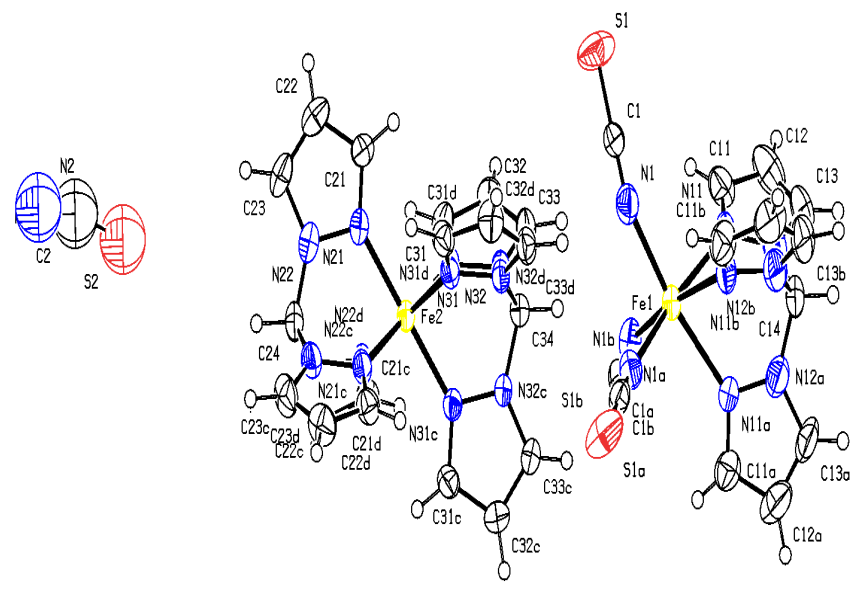

Figure 7. Unit of $\left[\mathrm{Fe}\left(\mathrm{HC}(\mathrm{pz})_{3}\right)_{2}\right]\left[\mathrm{Fe}\left(\mathrm{HC}(\mathrm{pz})_{3}\right)(\mathrm{NCS})_{3}\right] \mathrm{NCS} \cdot 2 \mathrm{H}_{2} \mathrm{O}$. 


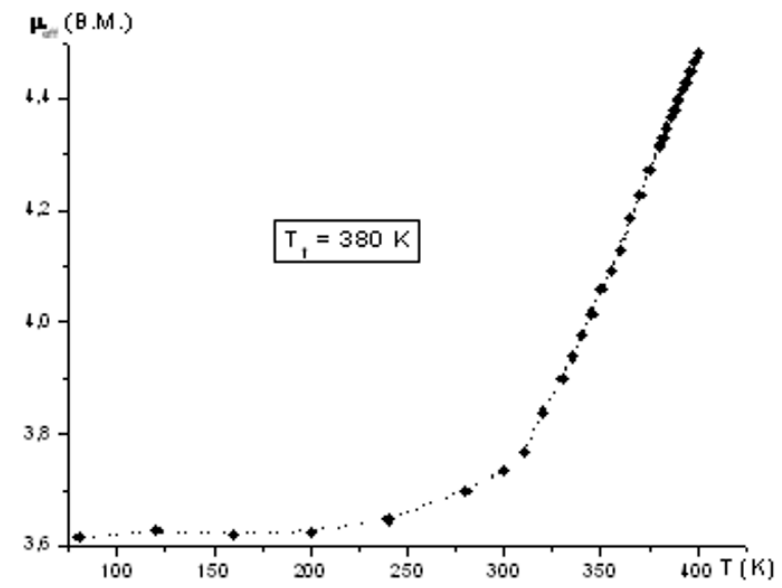

Figure 8. $\mu_{\mathrm{eff}}(\mathrm{T})$ curve of $\left[\mathrm{Fe}\left(\mathrm{HC}(\mathrm{pz})_{3}\right)_{2}\right]\left[\mathrm{Fe}\left(\mathrm{HC}(\mathrm{pz})_{3}\right)(\mathrm{NCS})_{3}\right] \mathrm{NCS}$.

Mössbauer spectra of complexes are poorly resolved lines with parameters (chemical shift $\delta$ and quadruple splitting $\varepsilon$ ) shown in Table 5 and Figure 9. The $\delta$ values are in the region of shifts characteristic of LS Fe(II) complexes, lower than those in previously studied Fe(II) complexes with 1,2,4-triazoles (0.416-0.427) [69], which gives evidence that chemical $\mathrm{Fe}-\mathrm{N}$ bonds in new complexes are more covalent. This fact, in turn, confirms the conclusion drawn in [20] that tris(pyrazol-1-yl)methane is a stronger field ligand in comparison with 1,2,4-triazole and 4-amino-1,2,4-triazole $\left(\mathbf{N H}_{\mathbf{2}} \mathbf{t r z}\right)$. This makes it possible to understand the main reason why SCO temperatures are higher in iron(II) complexes with $\mathrm{HC}(\mathrm{pz})_{3}$ than those in the complexes with 1,2,4-triazoles [70]. At the same time, there is no direct proportionality between $\mathrm{T}_{\mathrm{C}}$ and $\Delta_{\mathrm{LS}}$. Small quadruple splittings indicate a weak distortion of the octahedral environment of iron atoms in it (as in Fe(II) complexes with 1,2,4-triazoles).

Table 5. Basic Mössbauer parameters of the iron(II) complexes.

\begin{tabular}{cccc}
\hline Complex & $\mathrm{T}, \mathbf{K}$ & $\boldsymbol{\delta}, \mathbf{~} \mathbf{m} / \mathbf{s e c}$ & $\mathbf{\varepsilon}, \mathbf{~ m m} / \mathbf{s e c}$ \\
\hline$\left[\mathrm{Fe}\left(\mathrm{HC}(\mathrm{pz})_{3}\right)_{2}\right] \mathrm{I}_{2}$ & 295 & 0.404 & 0.24 \\
\hline$\left[\mathrm{Fe}\left(\mathrm{HC}(\mathrm{pz})_{3}\right)_{2}\right] \mathrm{Br}_{2}$ & 293 & 0.406 & 0.23 \\
\hline$\left[\mathrm{Fe}\left(\mathrm{HC}(\mathrm{pz})_{3}\right)_{2}\right]\left(\mathrm{SO}_{3} \mathrm{CF}_{3}\right)_{2}$ & 293 & 0.407 & 0.28 \\
\hline$\left[\mathrm{Fe}\left(\mathrm{HC}(\mathrm{pz})_{3}\right)_{2}\right]\left(\mathrm{ReO}_{4}\right)_{2}$ & 293 & 0.416 & 0.22 \\
\hline$\left[\mathrm{Fe}\left(\mathrm{HC}(\mathrm{pz})_{3}\right)_{2}\right] \mathrm{SO}_{4} \cdot 2 \mathrm{H}_{2} \mathrm{O}$ & 293 & 0.394 & 0.24 \\
\hline$\left[\mathrm{Fe}\left(\mathrm{HC}(\mathrm{pz})_{3}\right)_{2}\right] \mathrm{SiF}_{6}$ & 295 & 0.427 & 0.16 \\
\hline$\left[\mathrm{Fe}\left(\mathrm{HC}(\mathrm{pz})_{3}\right)_{2}\right]\left(7,8-\mathrm{C}_{2} \mathrm{~B}_{9} \mathrm{H}_{12}\right)_{2} \cdot 2 \mathrm{H}_{2} \mathrm{O}$ & 473 & 0.849 & 3.47 \\
\hline$\left[\mathrm{Fe}\left(\mathrm{HC}(\mathrm{pz})_{3}\right)_{2}\right]\left(1,5,6,10-\mathrm{Br}_{4}-7,8-\mathrm{C}_{2} \mathrm{~B}_{9} \mathrm{H}_{8}\right)_{2} \cdot 2 \mathrm{H}_{2} \mathrm{O}$ & 295 & 0.39 & 0.28 \\
\hline$\left[\mathrm{Fe}\left(\mathrm{HC}(\mathrm{pz})_{3}\right)_{2}\right]\left(1,5,6,10-\mathrm{I}_{4}-7,8-\mathrm{C}_{2} \mathrm{~B}_{9} \mathrm{H}_{8}\right)_{2}$ & 295 & 0.37 & 0.25 \\
\hline$\left[\mathrm{Fe}\left(\mathrm{HC}(\mathrm{pz})_{3}\right)_{2}\right]\left[\mathrm{Mo}_{6} \mathrm{Cl}_{14}\right] \cdot 2 \mathrm{H}_{2} \mathrm{O}$ & 295 & 0.37 & 0.38 \\
\hline$\left[\mathrm{Fe}\left(\mathrm{HC}(\mathrm{pz})_{3}\right)_{2}\right]\left[\mathrm{Mo}_{6} \mathrm{Br}_{14}\right] \cdot \mathrm{H}_{2} \mathrm{O}$ & & 0.500 & 0.341 \\
\hline$\left[\mathrm{Fe}\left(\mathrm{HC}(\mathrm{pz})_{3}\right)_{2}\right]_{2}\left[\mathrm{Re}_{6} \mathrm{~S}_{8}(\mathrm{CN})_{6}\right] \cdot 2 \mathrm{H}_{2} \mathrm{O}$ & 295 & 1.395 & 3.570 \\
\hline & & 0.476 & 0.279 \\
\hline
\end{tabular}


Table 5. Cont

\begin{tabular}{cccc}
\hline Complex & $\mathrm{T}, \mathbf{K}$ & $\boldsymbol{\delta}, \mathbf{m m} / \mathbf{s e c}$ & $\boldsymbol{\varepsilon}, \mathbf{m m} / \mathbf{s e c}$ \\
\hline & for comparison & & \\
\cline { 2 - 4 } $\mathrm{Fe}\left(\mathrm{NH}_{2} \text { trz }\right)_{3} \mathrm{SiF}_{6}$ & 293 & 1.04 & 2.78 \\
\hline $\mathrm{Fe}(\mathrm{Htrz})_{3} \mathrm{SiF}_{6}$ & 473 & $(>0.90)$ & $(<2.69)$ \\
\hline $\mathrm{Fe}(\mathrm{Htrz})_{3} \mathrm{I}_{2}$ & 293 & 0.42 & 0.26 \\
\hline$\delta$ & 295 & 0.42 & 0.25 \\
\hline
\end{tabular}
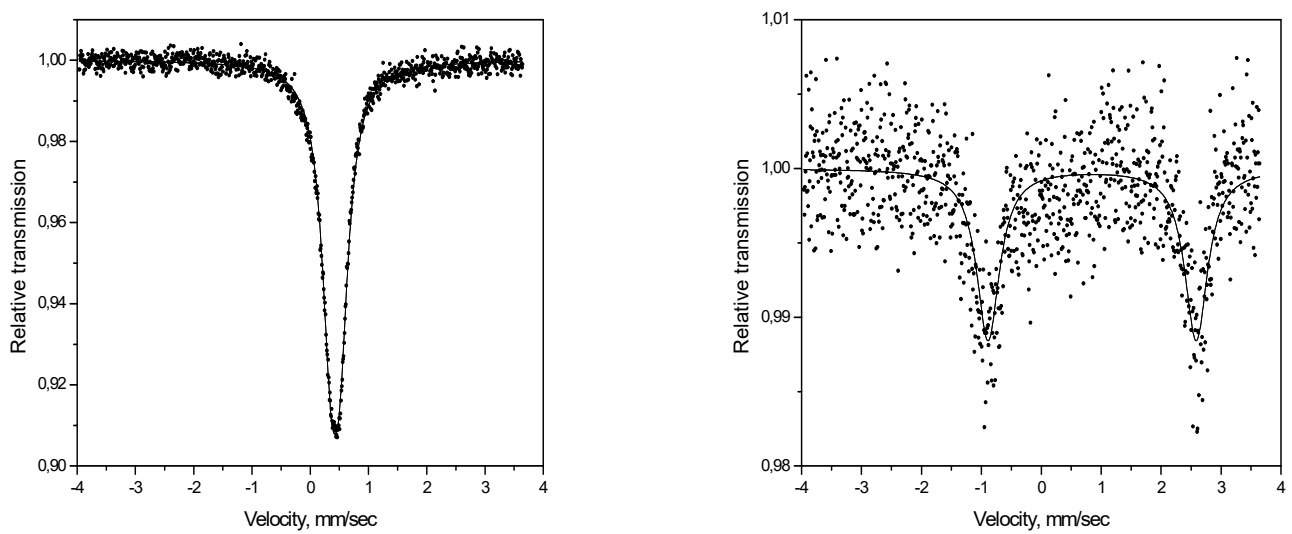

Figure 9. Mössbauer spectra of $\left[\mathrm{Fe}\left(\mathrm{HC}(\mathrm{pz})_{3}\right)_{2}\right] \mathrm{SiF}_{6}$ at $295 \mathrm{~K}$ (left) and at $473 \mathrm{~K}$ (right).

The measurements at $78 \mathrm{~K}$ show that the probability of the Mössbauer effect $\left(\mathrm{f}^{\prime}\right)$ in them approximately three times decreases with an increase in the temperature to $295 \mathrm{~K}$, which is appreciably stronger than that for Fe(II) complexes with 1,2,4-triazoles for which $\mathrm{f}^{\prime}$ lowers no more than 1.7 times. This fact can be related to the island structure of complexes and a weaker cation-anion interaction in comparison with the Fe(II) complexes with 1,2,4-triazoles having a polymeric chain structure. The consequence of this is the weakening of cooperative interactions in the lattices of such complexes, which decreases the ${ }^{1} \mathrm{~A}_{1} \leftrightarrow{ }^{5} \mathrm{~T}_{2}$ SCO abruptness.

Then we reported the synthesis and investigations of the complexes of $\mathrm{Fe}\left[\left(\mathrm{HC}(\mathrm{pz})_{3}\right)_{2}\right]^{2+}$ with functionalized calix[4]arenes [44,71] These complexes were obtained from solution by an exchange reaction between aqueous solutions of the complex $\mathrm{Fe}\left[\left\{\mathrm{HC}(\mathrm{pz})_{3}\right\}_{2}\right] \mathrm{SiF}_{6}$ (or sulfate, or nitrate) and the sodium salt of a $\mathrm{p}$-sulfonatothiacalix[4]arene (TC[4] $\left.\mathbf{A S}^{4-}\right)$, $\mathrm{p}$-sulfonatocalix[4]arene (C[4]AS $\left.{ }^{4-/ 5-}\right)$. Note that these were the first examples in which macrocyclic anions were used in the synthesis of compounds with SCO. For $\left[\mathrm{Fe}\left(\mathrm{HC}(\mathrm{pz})_{3}\right)_{2}\right]_{2}(\mathrm{TC}[4] \mathrm{AS})$, it was demonstrated by ${ }^{1} \mathrm{H}$ NMR spectroscopy that the $\mathrm{Fe}\left[\left(\mathrm{HC}(\mathrm{pz})_{3}\right)_{2}\right]^{2+}$ cation is partially immersed in the cyclophane cavity of $\mathrm{TCAS}^{4-}$. This complex exhibits high temperature spin crossover, $\mathrm{T}_{\mathrm{c}}=450 \mathrm{~K}$, without hysteresis in the $\mu_{\text {eff }}(\mathrm{T})$ dependence, which is accompanied by the thermochromism. The hydrated structures $\left[\mathrm{Fe}\left(\mathrm{HC}(\mathrm{pz})_{3}\right)_{2}\right]_{5}(\mathrm{C}[4] \mathrm{AS})_{2} \cdot \mathrm{nH}_{2} \mathrm{O}$ $(\mathrm{n}=16,62)$ and $\left[\mathrm{Fe}\left(\mathrm{HC}(\mathrm{pz})_{3}\right)_{2}\right]_{2}(\mathrm{C}[4] \mathrm{AS}) \cdot 24 \mathrm{H}_{2} \mathrm{O}$ have been analyzed by $\mathrm{X}$-ray diffraction (XRD) and revealed the outer sphere inclusion of $\left[\mathrm{Fe}\left(\mathrm{HC}(\mathrm{pz})_{3}\right)_{2}\right]^{2+}$ into the cyclophane cavity in each case (Figure 10). The magnetochemical investigation of $\mu_{\mathrm{eff}}(\mathrm{T})$ within the temperature range of 78-500 K has shown that the complex $\left[\mathrm{Fe}\left(\mathrm{HC}(\mathrm{pz})_{3}\right)_{2}\right]_{5}(\mathrm{C}[4] \mathrm{AS})_{2}$ (i.e., dehydrated) exhibits a high-temperature ${ }^{1} \mathrm{~A}_{1} \Leftrightarrow{ }^{5} \mathrm{~T}_{2}$ spin crossover (SCO), which is accompanied by thermochromism. The SCO temperature values $T_{\mathcal{C}} \uparrow$ and $T_{\mathcal{c}} \downarrow$ are equal to $390 \mathrm{~K}$ and $380 \mathrm{~K}$, respectively (Figure 11). The formation of inclusion complex of iron(II) tris(pyrazol-1-yl)methane complex with p-sulfonatocalix[4]arene leads to thermal stabilization and decreasing of SCO temperature. That allowed us to reach more preferred SCO 
characteristics (completeness, sharpness, room temperature range) for the compound, which can be used as a promising material for molecular sensors.

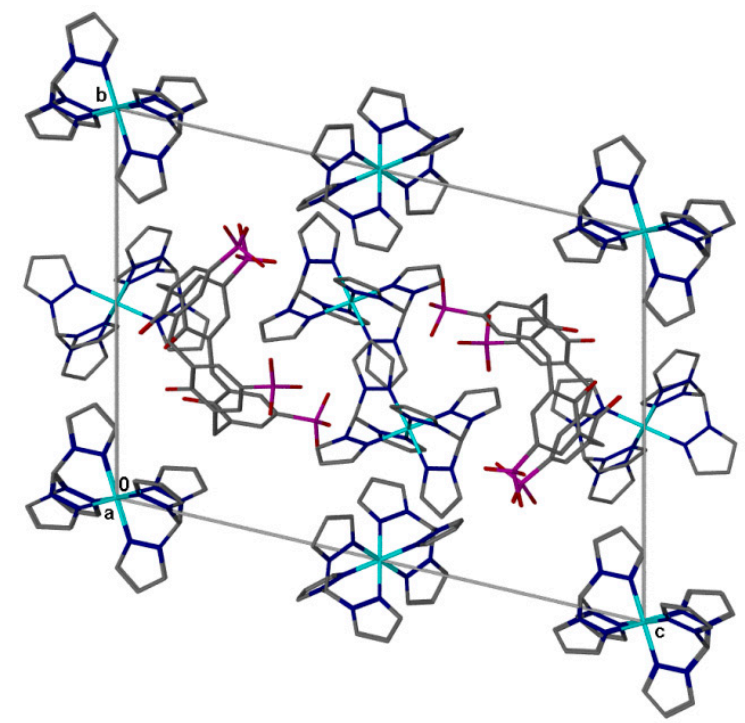

$\left[\mathrm{Fe}\left(\mathrm{HC}(\mathrm{pz})_{3}\right)_{2}\right]_{5}(\mathrm{C}[4] \mathrm{AS})_{2} \cdot 62 \mathrm{H}_{2} \mathrm{O}$

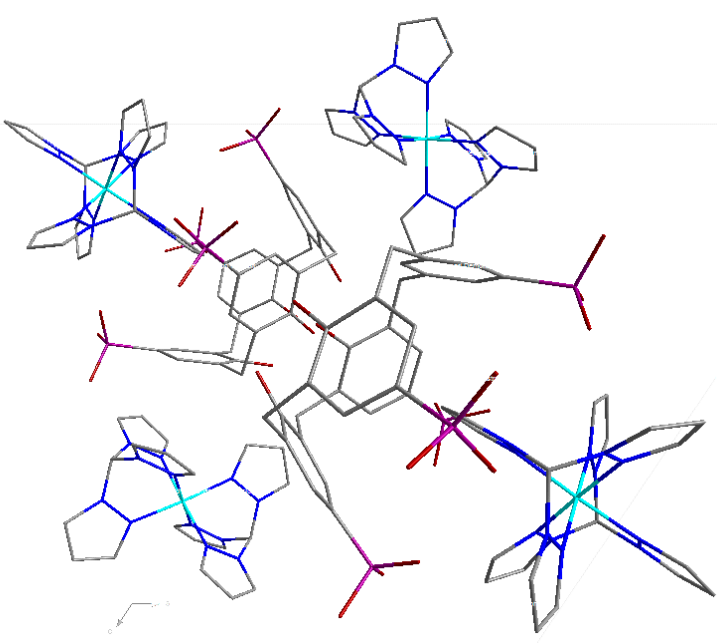

$\left[\mathrm{Fe}\left\{\mathrm{HC}(\mathrm{pz})_{3}\right\}_{2}\right]_{2}(\mathrm{C}[4] \mathrm{AS}) \cdot 24 \mathrm{H}_{2} \mathrm{O}$

Figure 10. Fragments of crystal structures illustrated the inclusion of $\left[\mathrm{Fe}\left\{\mathrm{HC}(\mathrm{pz})_{3}\right\}_{2}\right]^{2+}$ into the cavity of p-sulfonatocalix[4]arene (crystallization water is not shown for clarity).

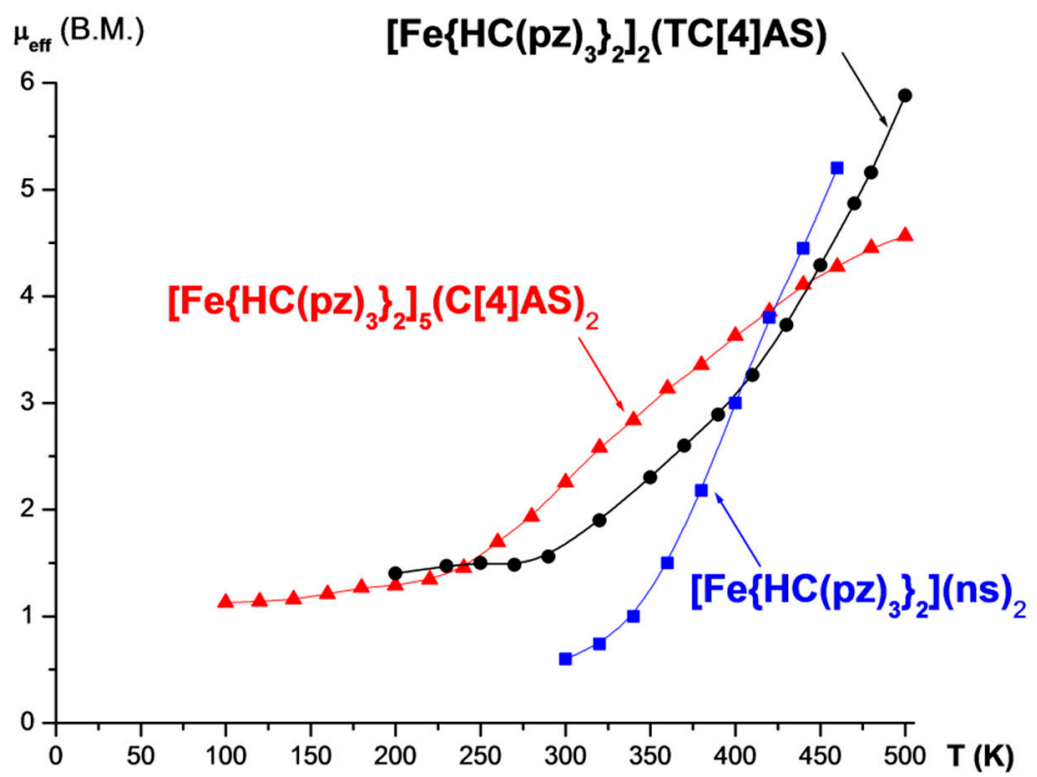

Figure 11. The $\mu_{\text {eff }}(\mathrm{T})$ plots for $\left[\mathrm{Fe}\left(\mathrm{HC}(\mathrm{pz})_{3}\right)_{2}\right]_{5}(\mathrm{C}[4] \mathrm{AS})_{2},\left[\mathrm{Fe}\left(\mathrm{HC}(\mathrm{pz})_{3}\right)_{2}\right]_{2}(\mathrm{TC}[4] \mathrm{AS})$, and their comparison with $\left[\mathrm{Fe}\left(\mathrm{HC}(\mathrm{pz})_{3}\right)_{2}\right](\mathrm{ns})_{2}$ (where ns = 2-naphthalenesulfonate $\mathrm{C}_{10} \mathrm{H}_{7} \mathrm{SO}_{3}{ }^{-}$).

The heteroligand iron(II) complexes, which contain in the internal sphere other nitrogen-containing heterocycles (pyridine (Py), 4,4'-bipyridyl (Bipy), imidazole (im), $\mathrm{NCS}^{-}, \mathrm{NCSe}^{-}$[72], tetrazole (Tz), pyrazole (Pz), 3,5-dimethylpyrazole (3,5-( $\left.\left(\mathrm{CH}_{3}\right)_{2} \mathrm{pz}\right)$, 3-amino-4-ethoxycarbonylpyrazole (Ametcpz), and phthalazine (Phz) [73]), along with tris(pyrazol-1-yl) methanes, were synthesized and studied. Specific features of the SCO and their dependence on the ligand complexes are discussed. The study of the temperature dependence $\mu_{\text {eff }}(\mathrm{T})$ within the temperature range 2-350 K showed the gradual and incomplete spin crossover ${ }^{1} \mathrm{~A}_{1} \leftrightarrow{ }^{5} \mathrm{~T}_{2}$ accompanied by thermochromism (color change "pink $\leftrightarrow$ 
colorless") in complexes $\left[\mathrm{Fe}\left(\mathrm{HC}\left(3,5-\left(\mathrm{CH}_{3}\right)_{2} \mathrm{pz}\right)_{3}\right)(\mathrm{Tz})_{3}\right]\left(\mathrm{NO}_{3}\right)_{2}$, $\left[\mathrm{Fe}\left(\mathrm{HC}\left(3,5-\left(\mathrm{CH}_{3}\right)_{2} \mathrm{pz}\right)_{3}\right)(\mathrm{Tz})_{3}\right]\left(\mathrm{ClO}_{4}\right)_{2}$, and $\left[\mathrm{Fe}\left(\mathrm{HC}\left(3,5-\left(\mathrm{CH}_{3}\right)_{2} \mathrm{pz}\right)_{3}\right)(\mathrm{Aecpz})(\mathrm{NCS})_{2}\right]$ only. The compounds with py, bipy, im, $\mathrm{NCS}^{-}$, and $\mathrm{NCSe}^{-}$ are all high-spin between 5 and $300 \mathrm{~K}$, despite mostly having regular coordination geometries and tripodal ligand conformations that should favor spin-crossover. Doubtlessly, the ligand field is too weak to make the low-spin forms of the compounds accessible.

\section{Conclusions}

An analysis of the data, being the subject of this review, demonstrates that, there is an essentially marked temperature dependence of the SCO (including the abruptness of the transition, the presence or absence of hysteresis) on the ligand structure and its composition, the nature of the outer-sphere anion, and also on the presence of solvent molecules. This pronounced dependence of $T_{c}$ can be explained by the ability of anions and the lattice solvent molecules to form a hydrogen network with the coordinated ligands. It is typical both for polynuclear complexes with 1,2,4-triazoles and island complexes with B/C-scorpionates. Effective intermolecular interactions can be created also through $\pi$ stacking. The effect of an outer-sphere anion is also manifested by the creation of an additional electrostatic field by the anion (ionic atmosphere), which results in additional splitting of the terms of the HS and LS electronic configurations of the central atom and causes SCO. Hence, the prediction of $\mathrm{T}_{\mathrm{c}}$ on the nature of the ligand and the anion can be used with a number of restrictions because the SCO-phenomenon depends on several factors, which are working synchronously.

For complexes with tris(pyrazol-1-yl)methane, tris(pyrazol-1-yl)borate, and its derivatives, one can observe either abrupt SCO or gradual transitions, sometimes with small hysteresis. At the same time, the Fe(II) complexes with tris(pyrazol-1-yl)methane have remarkably higher values of $\mathrm{T}_{\mathrm{C}}$ than the complexes with 1,2,4-triazoles and B-scorpionates. The substituent introduction in the ligand composition reduces the field strength and $T_{c}$ of complexes. The introduction of an amino group affects $T_{c}$ to a much lesser extent than the introduction of alkyl substituents. Thus, the strength of the ligand field is the main determining factor for the spin-crossover temperature, but the nature of the transition (abruptness and hysteresis) is most significantly affected by the structure of the complex. It is necessary to remember that SCO is not only a two-electron but also a phase transition, the main driving factor of which is a change in entropy. According to the calculations performed, the oscillatory component makes the most significant contribution to the entropy change at SCO.

The spin-crossover for complexes with Rtrz is sharper in comparison with complexes with $\mathrm{HC}(\mathrm{pz})_{3}$. In most cases, there is a hysteresis on the curves of the dependence $\mu_{\mathrm{eff}}(\mathrm{T})$. This is due to a high degree of cooperative effect in complexes with Rtrz, which have a polynuclear structure. In some cases, in the low-temperature region, the $\mu_{\text {eff }}(T)$ curve during cooling passes significantly higher than the curve during heating, which is explained by kinetic difficulties in the process of transition HS $\rightarrow$ LS in the low-temperature region. It is interesting to note that there is no direct relationship between the sharpness of the transition and its $\mathrm{T}_{\mathrm{c}}$; moreover, the $\mathrm{T}_{\mathrm{c}}$ can both increase and decrease during complexes dehydration.

The analysis of the results accumulated for Fe(II) complexes with B- and C-scorpionates shows that a promising class of compounds with SCO systems, despite the significant array of data obtained, deserves further research.

Supplementary Materials: The following are available online at http://www.mdpi.com/2073-4352/10/9/843/s1, Table S1: Scaling factors for the force fields of the compounds studied.

Author Contributions: Writing review and editing, O.G.S.; supervision, L.G.L. All authors have read and agreed to the published version of the manuscript.

Funding: This research was funded by RUSSIAN SCIENCE FOUNDATION, grant number 20-63-46026.

Conflicts of Interest: The authors declare no conflict of interest. 


\section{References}

1. Gütlich, P.; Goodwin, H.A. (Eds.) Spin Crossover in Transition Metal Compounds: I-III. In Topics in Current Chemistry; Springer: Berlin/Heidelberg, Germany, 2004; pp. 233-235.

2. Bousseksou, A.; Molnar, G.; Salmon, L.; Nicolazzi, W. Molecular spin crossover phenomenon: Recent achievements and prospects. Chem. Soc. Rev. 2011, 40, 3313-3335. [CrossRef] [PubMed]

3. Halcrow, M.A. (Ed.) Spin-Crossover Materials: Properties and Applications; John Wiley \& Sons: Hoboken, NJ, USA, 2013; 568p, ISBN 978-1-118-51931-8.

4. Levchenko, G.G.; Khristov, A.V.; Varyukhin, V.N. Spin crossover in iron(II)-containing complex compounds under a pressure. Low Temp. Phys. 2014, 40, 571-585. [CrossRef]

5. Gütlich, P.; Goodwin, H.A. Spin crossover-an overall perspective. In Spin Crossover in Transition Metal Compounds I; Springer: Berlin/Heidelberg, Germany, 2004; Volume 233, pp. 1-47.

6. Gütlich, P. Photoswitchable coordination compound. Coord. Chem. Rev. 2001, 219-221, 839-879. [CrossRef]

7. Boillot, M.-L.; Zarembowitch, J.; Sour, A. Ligand-Driven Light-Induced Spin Change (LD-LISC): A promising photomagnetic effect. In Spin Crossover in Transition Metal Compounds I; Springer: Berlin/Heidelberg, Germany, 2004; Volume 23, pp. 261-276.

8. Miller, R.G.; Brooker, S. Reversible quantitative guest sensing via spin crossover of an iron(II) triazole. Chem. Sci. 2016, 7, 2501-2505. [CrossRef] [PubMed]

9. Goodwin, H.A. Spin transitions in six-coordinate iron(II) complexes. Coord. Chem. Rev. 1976, 18, $293-325$. [CrossRef]

10. Gütlich, P. Spin crossover in iron(II) complexes. In Metal Complexes; Bau, R., Gütlich, P., Teller, R.G., Eds.; Structure and Bonding; Springer: Berlin/Heidelberg, Germany, 1981; Volume 44, pp. 83-195. [CrossRef]

11. König, E.; Ritter, G.; Kulshreshtha, S.K. The nature of spin-state transitions in solid complexes of iron(II) and the interpretation of some associated phenomena. Chem. Rev. 1985, 85, 219-234. [CrossRef]

12. Lavrenova, L.G.; Ikorskii, V.N.; Varnek, V.A.; Oglezneva, I.M.; Lavrionov, S.V. High-temperature spin transition in iron(II) coordination compounds with triazoles. Soviet J. Coord. Chem. 1986, 12, 207-215.

13. Olguín, J. Unusual metal centres/coordination spheres in spin crossover compounds. Coord. Chem. Rev. 2020, 407, 213148. [CrossRef]

14. Gutlich, P.; Garcia, Y.; Goodwin, H.A. Spin crossover phenomena in Fe(II) complexes. Chem. Soc. Rev. 2000, 29, 419-427. [CrossRef]

15. Kahn, O.; Martinez, C.J. Spin-transition polymers: From molecular materials toward memory devices. Science 1998, 279, 44-48. [CrossRef]

16. Bousseksou, A.; Vieu, C.; Letard, J.-F.; Demont, P.; Tuchagues, J.-P.; Malaquin, L.; Menegotto, J.; Salmon, L. Molecular Memory and Method for Making Same. European Patent 1430552A1, 23 June 2004.

17. Matsuda, M.; Isozaki, H.; Tajima, H. Electroluminescence quenching caused by a spin-crossover transition. Chem. Lett. 2008, 37, 374-375. [CrossRef]

18. Muller, R.N.; Elst, V.; Laurent, S. Spin transition molecular materials: Intelligent contrast agents for magnetic resonance imaging. J. Am. Chem. Soc. 2003, 125, 8405-8407. [CrossRef] [PubMed]

19. Kahn, O.; Jay, C.; Garcia, Y.; Codjovi, E.; Philips Electronics, NV. Chemical Spin Transition Compounds Comprising Metal-Ligand Molecules Assotiated with Anion-Useful as Indicators of Temperature Increase Above a Threshold and Incorporated as Anti-Falsifiable Markers. European Patent 842988, 4 November 1996.

20. Lavrenova, L.G.; Shakirova, O.G. Spin crossover and thermochromism of iron(II) coordination compounds with 1,2,4-triazoles and tris(pyrazol-1-yl)methanes. Eur. J. Inorg. Chem. 2013, 5-6, 670-682. [CrossRef]

21. Hamon, P.; Thépot, J.-Y.; Le Floch, M.; Boulon, M.-E.; Cador, O.; Golhen, S.; Ouahab, L.; Fadel, L.; Saillard, J.-Y.; Hamon, J.-R. Dramatic Remote Substitutent Effects on the Electronic Spin State of Bis(scorpionate) Iron(II) Complexes. Angew. Chem. Int. Ed. 2008, 47, 8687-8691. [CrossRef]

22. Vitze, H.; Bolte, M.; Lerner, H.-W.; Wagner, M. Third-Generation Scorpionates [RBpz $]^{-}$-How Influential Is the Nondonor Substituent R? Eur. J. Inorg. Chem. 2016, 15-16, 2443-2454. [CrossRef]

23. Gruden-Pavlovic, M.; Stepanovic, S.; Peric, M.; Güell, M.; Swart, M. A density functional study of the spin state energetics of polypyrazolylborato complexes of first-row transition metals. Phys. Chem. Chem. Phys. 2014, 16, 14514-14522. [CrossRef]

24. Trofimenko, S. Geminal poly(1-pyrazolyl)alkanes and their coordination chemistry. J. Am. Chem. Soc. 1970, 92, 5118-5126. [CrossRef] 
25. Mani, F. Four-, five-, and six-co-ordinated iron(II) complexes with poly(1-pyrazolyl)methanes. Inorg. Nucl. Chem. Lett. 1979, 15, 297-302. [CrossRef]

26. Bigmore, H.R.; Lawrence, S.C.; Mountford, P.; Tredget, C.S. Coordination, organometallic and related chemistry of tris(pyrazolyl)methane ligands. Dalton Trans. 2005, 635-651. [CrossRef]

27. Jesson, J.P.; Trofimenko, S.; Eaton, D.R. Spin equilibria in octahedral iron(II) poly(1-pyrazolyl)borates. J. Am. Chem. Soc. 1967, 89, 3158-3164. [CrossRef]

28. Buchen, Th.; Gütlich, P. Substituent effects on the spin equilibrium in iron(II) pyrazolylborate complexes. Inorg. Chim. Acta 1995, 231, 221-223. [CrossRef]

29. Halcrow, M.A. The effect of ligand design on metal ion spin state-Lessons from spin crossover complexes. Crystals 2016, 6, 58. [CrossRef]

30. Ikorskii, V.N. Effect of water on spin transitions in Fe(II) complexes with triazoles. Dokl. Phys. Chem. 2001, 377, 77-79. [CrossRef]

31. Lavrenova, L.G.; Kirillova, E.V.; Ikorskii, V.N.; Shvedenkov, Y.G.; Varnek, V.A.; Sheludyakova, L.A.; Larionov, S.V. Iron(II) complexes with 4-R-1,2,4-triazoles ( $\mathrm{r}=$ ethyl, propyl) exhibiting ${ }^{1} \mathrm{~A}_{1} \leftrightarrow{ }^{5} \mathrm{~T}_{2}$ spin transition. Russ. J. Coord. Chem. 2001, 27, 46-50. [CrossRef]

32. Luo, Y.-H.; Yang, L.-J.; Liu, Q.-L.; Ling, Y.; Wang, W.; Sun, B.-W. Lattice water molecules tuned spin-crossover for an iron(II) complex with thermal hysteresis. Dalton Trans. 2014, 43, 16937-16942. [CrossRef]

33. Bushuev, M.B.; Pishchur, D.P.; Korolkov, I.V.; Vinogradova, K.A. Prototypical iron(II) complex with 4-amino-1,2,4-triazole reinvestigated: An unexpected impact of water on spin transition. Phys. Chem. Chem. Phys. 2017, 19, 4056-4068. [CrossRef]

34. McGarvey, J.J.; Toftlund, H.; Al-Obaidi, A.H.R.; Taylor, K.P.; Bell, S.E.J. Photoperturbation of the ${ }^{1} \mathrm{~A} \Leftrightarrow \Leftrightarrow^{5} \mathrm{~T}$ spin equilibrium in an iron(II) complex in solution via ligand field excitation. Inorg. Chem. 1993, 32, 2469-2472. [CrossRef]

35. Long, G.J.; Grandjean, F.; Reger, D.L. Spin crossover in pyrazolylborate and pyrazolylmethane complexes. In Spin Crossover in Transition Metal Compounds I; Springer: Berlin/Heidelberg, Germany, 2004; Volume 233, pp. 91-122.

36. Reger, D.L.; Little, C.A.; Rheingold, A.L.; Lam, M.; Liable-Sands, L.M.; Rhagitan, B.; Concolino, T.; Mohan, A.; Long, G.J.; Briois, V.; et al. A Synthetic, structural, magnetic, and spectral study of several $\left.\{\mathrm{Fe} \text { [tris(pyrazolyl)methane }]_{2}\right\}\left(\mathrm{BF}_{4}\right)_{2}$ complexes: observation of an unusual spin-state crossover. Inorg. Chem. 2001, 40, 1508-1520. [CrossRef]

37. Anderson, P.A.; Astley, T.; Hitchman, M.A.; Keene, F.R.; Moubaraki, B.; Murray, K.S.; Skelton, B.W.; Tiekink, E.R.T.; Toftlund, H.; White, A.H. Structures and spectra of bis-tripodal iron(II) chelates, $\left[\mathrm{FeL}_{2}\right]^{2+}$, where $\mathrm{L}=$ tris(pyrazol-1-yl)methane, tris(pyridin-2-yl)methane, bis(pyrazol-1-yl)(pyridin-2-yl)methane and tris(pyridin-2-yl)phosphine oxide. Magnetism and spin crossover in the (pz) 3 CH case. Dalton Trans. 2000, 20, 3505-3512. [CrossRef]

38. Kuzu, I.; Krummenacher, I.; Hewitt, I.J.; Lan, Y.; Mereacre, V.; Powell, A.K.; Hofer, P.; Harmer, J.; Breher, F. Syntheses, structures and electronic properties of zwitterionic iron(II) and cobalt(II) complexes featuring ambidentate tris(pyrazolyl)methanide ligands. Chem. Eur. J. 2009, 15, 4350-4365. [CrossRef]

39. Reger, D.L.; Little, C.A.; Smith, M.D.; Rheingold, A.L.; Lam, K.-C.; Concolino, T.L.; Long, G.J.; Hermann, R.P.; Grandjean, F. Synthetic, structural, magnetic, and mössbauer spectral study of $\left\{\mathrm{Fe}\left[\mathrm{HC}\left(3,5-\mathrm{Me}_{2} \mathrm{pz}\right)_{3}\right]_{2}\right\} \mathrm{I}_{2}$ and its spin-state crossover behavior. Eur. J. Inorg. Chem. 2002, 5, 1190-1197. [CrossRef]

40. Lavrenova, L.G.; Virovets, A.V.; Peresypkina, E.V.; Strekalova, A.D.; Piryazev, D.A.; Daletsky, V.A.; Sheludyakova, L.A.; Vasilevsky, S.F. Spin-crossover in the complex of iron(II) nitrate with tris(3,5-dimethylpyrazol-1-yl)methane. Inorg. Chim. Acta 2012, 382, 1-5. [CrossRef]

41. Reger, D.L.; Little, C.A.; Rheingold, A.L.; Lam, M.; Concolino, T.; Mohan, A.; Long, G.J. Structural, electronic, and magnetic properties of $\left\{\mathrm{Fe}\left[\mathrm{HC}\left(3,5-\mathrm{Me}_{2} \mathrm{pz}\right)_{3}\right]_{2}\right\}\left(\mathrm{BF}_{4}\right)_{2}(\mathrm{pz}=$ pyrazolyl): Observation of unusual spin-crossover behavior. Inorg. Chem. 2000, 39, 4674-4675. [CrossRef] [PubMed]

42. Lavrenova, L.G.; Strekalova, A.D.; Virovets, A.V.; Piryazev, D.A.; Daletskii, V.A.; Sheludyakova, L.A.; Mikhailovskaya, T.F.; Vasilevskii, S.F. Spin crossover in the coordination compounds of iron(II) with tris(3,5-dimethylpyrazol-1-yl)methane. Russ. J. Coord. Chem. 2012, 38, 507-514. [CrossRef]

43. Shakirova, O.G.; Lavrenova, L.G.; Kuratieva, N.V.; Naumov, D.Yu.; Daletsky, V.A.; Sheludyakova, L.A.; Logvinenko, V.A.; Vasilevsky, S.F. Spin crossover in iron(II) complexes with tris(pyrazol-1-yl)methane. Russ. J. Coord. Chem. 2010, 36, 275-283. [CrossRef] 
44. Shakirova, O.G.; Lavrenova, L.G.; Daletsky, V.A.; Shusharina, E.A.; Griaznova, T.P.; Katsyuba, S.A.; Syakaev, V.V.; Skripacheva, V.V.; Mustafina, A.R.; Solovieva, S.E. High-temperature spin-crossover in coordination compounds of iron(II) with tris(pyrazol-1-yl)methane. Inorg. Chim. Acta 2010, 363, 4059-4064. [CrossRef]

45. Shakirova, O.G.; Daletsky, V.A.; Lavrenova, L.G.; Kuratieva, N.V.; Shusharina, E.A.; Sheludyakova, L.A.; Vasilevsky, S.F. High-temperature spin transition in the iron(II) trifluoromethylsulfonate, perrhenate, and tetraphenylborate complexes with tris(pyrazol-1-yl)methane. Russ. J. Coord. Chem. 2011, 37, 511-517. [CrossRef]

46. Shakirova, O.G.; Daletskii, V.A.; Lavrenova, L.G.; Trubina, S.V.; Erenburg, S.B.; Zhizhin, K.Y.; Kuzhetsov, N.T. Iron(II) closo-borate complexes with 1,2,4-triazole derivatives: Spin crossover in the iron(II) closo-borate complexes with tris(pyrazol-1-yl)methane. Russ. J. Inorg. Chem. 2013, 58, 650-656. [CrossRef]

47. Shakirova, O.G.; Kuratieva, N.V.; Korotaev, E.V.; Lavrenova, L.G. New iron(II) complexes $\left[\mathrm{Fe}\left(\mathrm{HC}(\mathrm{pz})_{3}\right)_{2}\right] \mathrm{A}_{2}$ with spin-crossover. Solid State Phenomena. 2015, 233-234, 534-537. [CrossRef]

48. Shakirova, O.G.; Lavrenova, L.G.; Korotaev, E.V.; Sheludyakova, L.A.; Varnek, V.A.; Shestopalov, M.A.; Mironov, Y.V. Spin-crossover in coordination compounds of iron(II) with tris(pyrazol-1-yl)methane and cluster anions. J. Struct. Chem. 2015, 56, 1520-1526. [CrossRef]

49. Shakirova, O.G.; Korotaev, E.V.; Evtushok, D.V.; Kuratieva, N.V.; Sheludyakova, L.A.; Shestopalov, M.A.; Lavrenova, L.G. Spin-crossover in iron(II) complexes with tris(pyrazol-1-yl)methane and cluster anions $\left[\left\{\mathrm{W}_{6} \mathrm{X}_{8}\right\} \mathrm{X}_{6}\right]^{2-}(\mathrm{X}=\mathrm{Cl}, \mathrm{Br}, \mathrm{I})$. J. Mol. Struct. 2019, 1193, 1-6. [CrossRef]

50. Moubaraki, B.; Leita, B.A.; Halder, G.J.; Betten, S.R.; Jensen, P.; Smith, J.P.; Cashion, J.D.; Kepert, C.J.; Letard, J.-F.; Murray, K.S. Structure, magnetism and photomagnetism of mixed-ligand tris(pyrazolyl)methane iron(II) spin crossover compounds. Dalton Trans. 2007, 39, 4413-4426. [CrossRef] [PubMed]

51. Guionneau, P.; Marchivie, M.; Bravic, G.; L'etard, J.-F.; Chasseau, D. Structural aspects of spin crossover. Example of the $\left[\left(\mathrm{FeL}_{n}\right)(\mathrm{NCS})_{2}\right]$ complexes. In Spin Crossover in Transition Metal Compounds II; Springer: Berlin/Heidelberg, Germany, 2004; Volume 234, pp. 97-128.

52. Lever, A.B.P. Inorganic Electronic Spectroscopy, 2nd ed.; Elsevier: Amsterdam, The Netherlands, 1985; 864p, ISBN 978-0-444-42389-4.

53. Griaznova, T.P.; Katsyuba, S.A.; Shakirova, O.G.; Lavrenova, L.G. Variable temperature ir spectroscopy and quantum chemistry as the tool for diagnostics of metal spin state. Chem. Phys. Lett. 2010, 495, 50-54. [CrossRef]

54. Lavrenova, L.G.; Larionov, S.V. Spin Transition in Iron(II) Complexes with 1,2,4-Triazoles and Tetrazoles. Russ. J. Coord. Chem. 1998, 24, 379-395.

55. Hauser, A. Ligand field theoretical considerations. In Spin Crossover in Transition Metal Compounds I; Springer: Berlin/Heidelberg, Germany, 2004; Volume 233, pp. 49-58.

56. Sugano, S.; Tanabe, Y.; Kamimura, H. Multiplets of Transition Metal Ions in Crystals; Pure and Applied Physics; Academic Press: Cambridge, MA, USA, 1970; Volume 33, 333p, ISBN 978-0-126-76050-7.

57. Larionov, S.V. Crystal-field parameters for the low-spin nitrous-heterocycle-containing iron(II) complexes possessing spin transition. Russ. J. Coord. Chem. 1999, 25, 408-410.

58. Sugiyarto, K.H.; Goodwin, H.A. Cooperative Spin Transitions in Iron(II) Derivatives of 1,2,4-Triazole. Aust. J. Chem. 1994, 47, 263-277. [CrossRef]

59. Lavrenova, L.G.; Shakirova, O.G.; Ikorskii, V.N.; Varnek, V.A.; Sheludyakova, L.A.; Larionov, S.V. ${ }^{1} \mathrm{~A}_{1} \leftrightarrow$ ${ }^{5} \mathrm{~T}_{2}$ spin transition in new thermochromic iron(II) complexes with 1,2,4-triazole and 4-amino-1,2,4-triazole. Russ. J. Coord. Chem. 2003, 29, 22-27. [CrossRef]

60. Real, J.A.; Gaspar, A.B.; Munoz, M.C. Thermal, pressure and light switchable spin-crossover materials. Dalton Trans. 2005, 2062-2079. [CrossRef]

61. Shakirova, O.G.; Lavrenova, L.G.; Bogomyakov, A.S.; Zhizhin, K.Y.; Kuznetsov, N.T. Synthesis and Magnetic Properties of Iron(II) closo-Borate Complexes with Tris(3,5-Dimethylpyrazol-1-yl)Methane. Russ. J. Inorg. Chem. 2015, 60, 786-789. [CrossRef]

62. Shakirova, O.G.; Lavrenova, L.G.; Korotaev, E.V.; Kuratieva, N.V.; Burdukov, A.B.; Kolokolov, F.A. Structure and spin crossover in an iron(II) compound with tris(pyrazol-1-yl)methane and the complex $\left[\text { Eu(dipic) }{ }_{2} \text { (Hdipic) }\right]^{2-}$ anion. J. Struct. Chem. 2016, 57, 471-477. [CrossRef] 
63. Shvachko, Y.N.; Starichenko, D.V.; Korolyov, A.V.; Yagubskii, E.B.; Kotov, A.I.; Buravov, L.I.; Lyssenko, K.A.; Zverev, V.N.; Simonov, S.V.; Zorina, L.V.; et al. The Conducting Spin-Crossover Compound Combining Fe(II) Cation Complex with TCNQ in a Fractional Reduction State. Inorg. Chem. 2016, 55, 9121-9130. [CrossRef] [PubMed]

64. Nihei, M.; Tahira, H.; Takahashi, N.; Otake, Yu.; Yamamura, Y.; Saito, K.; Oshio, H. Multiple bi-stability and tristability with dual spin-state conversions in $\left[\mathrm{Fe}(\mathrm{dpp})_{2}\right]\left[\mathrm{Ni}(\mathrm{mnt})_{2}\right]_{2} \cdot \mathrm{MeNO}_{2}$. J. Am. Chem. Soc. 2010, 132, 3553-3560. [CrossRef] [PubMed]

65. Szafranowska, B.; Landvogt, C.; Beck, J. Structural Chemistry of Tetracyanopyrrolide (Part 2): Spin Crossover in a Bis-Tripodal Iron(II) Complex. Z. Für Anorg. Und Allg. Chem. 2015, 641, 176-179. [CrossRef]

66. Karlin, R. Magnetochemistry; Springer: Berlin/Heidelberg, Germany, 1986; 328p, ISBN 978-3-642-70735-3.

67. Shakirova, O.G.; Lavrenova, L.G.; Naumov, D.Y.; Daletsky, V.A.; Sheludyakova, L.A. High-temperature spin crossover in the $\left[\mathrm{FeL}_{2}\right]\left[\mathrm{FeL}(\mathrm{NCS})_{3}\right](\mathrm{NCS}) \cdot 2 \mathrm{H}_{2} \mathrm{O}$ complex, $\mathrm{L}=$ tris(pyrazol-1-yl)methane. Polyhedron 2012, 31, 64-68. [CrossRef]

68. Lavrenova, L.G.; Strekalova, A.D.; Smolentsev, A.I.; Naumov, D.Yu.; Bogomyakov, A.S.; Sheludyakova, L.A.; Vasilevskii, S.F. Mono- and heteroligand iron(II) complexes with tris(3,5-dimethylpyrazol-1-yl)methane. Russ. J. Coord. Chem. 2016, 42, 711-718. [CrossRef]

69. Varnek, V.A.; Lavrenova, L.G. Исследование методом мессбауэровской спектроскопии природы влияния лиганда и внешнесферногоаниона в комплексах железа (II) с1,2,4-триазолом и4-амино-1,2,4-триазолом на температуру спинового перехода ${ }^{1} \mathrm{~A}_{1} \leftrightarrow{ }^{5} \mathrm{~T}_{2}$. Zhurn. Struktur. Khimii. 1995, 36, 120-127. (In Russian). Available online: https://jsc.niic.nsc.ru/article/16017/ (accessed on 21 September 2020).

70. Varnek, V.A. Упрощенная формула для температуры спинового перехода ${ }^{1} \mathrm{~A}_{1} \Leftrightarrow{ }^{5} \mathrm{~T}_{2}$ в комплексахFе(II). Zhurn. Struktur. Khimii. 1994, 35, 94-102. (In Russian). Available online: https://jsc.niic.nsc.ru/article/24469/ (accessed on 21 September 2020).

71. Shakirova, O.; Kuratieva, N.; Korotaev, E.; Lavrenova, L.; Ovsyannikov, A.; Antipin, I.; Solovieva, S. Synthesis, crystal structures and high-temperature spin-crossover of new inclusion compounds of iron(II) tris(pyrazol-1-yl)methane complex with p-sulfonatocalix[4]arene. Inorg. Chim. Acta 2018, 476, 129-135. [CrossRef]

72. Salaudeen, A.A.; Kilner, C.A.; Halcrow, M.A. Mononuclear and dinuclear iron thiocyanate and selenocyanate complexes of tris-pyrazolylmethane ligands. Polyhedron 2008, 27, 2569-2576. [CrossRef]

73. Lavrenova, L.G. Spin crossover in homo- and heteroligand iron(II) complexes with tris(pyrazol-1-yl)methane derivatives. Russ. Chem. Bull. Int. Ed. 2018, 67, 1142-1152. [CrossRef]

(C) 2020 by the authors. Licensee MDPI, Basel, Switzerland. This article is an open access article distributed under the terms and conditions of the Creative Commons Attribution (CC BY) license (http://creativecommons.org/licenses/by/4.0/). 